Elsevier required licence: (C) <2021>. This manuscript version is made available under the CC-BY-NCND 4.0 license http://creativecommons.org/licenses/by-nc-nd/4.0/

The definitive publisher version is available online at

[https://www.sciencedirect.com/science/article/pii/S1364032121002148?via\%3Dihub] 


\section{Dual injection: An effective and efficient technology to use renewable fuels in spark ignition engines}

Yuhan Huang ${ }^{1, *}$, Nic C. Surawski ${ }^{1}$, Yuan Zhuang ${ }^{2, *}$, John L. Zhou ${ }^{1}$, Guang Hong ${ }^{3}$

${ }^{1}$ Centre for Green Technology, School of Civil and Environmental Engineering, University of Technology Sydney, NSW 2007, Australia

${ }^{2}$ School of Automotive and Transportation Engineering, Hefei University of Technology, Hefei, China

${ }^{3}$ School of Mechanical and Mechatronic Engineering, University of Technology Sydney, NSW 2007, Australia

Corresponding authors:

Dr Yuhan Huang, Email: yuhan.huang@uts.edu.au, Phone: +61-0-415040942

Dr Yuan Zhuang, Email: zhuangyuan@hfut.edu.cn, Phone: +86-13920110876

Please cite this article as:

Y. Huang, N.C. Surawski, Y. Zhuang, J.L. Zhou, G. Hong. Dual injection: An effective and efficient technology to use renewable fuels in spark ignition engines. Renewable and Sustainable Energy Reviews 2021; 143: 110921. https://doi.org/10.1016/j.rser.2021.110921 


\begin{abstract}
Modern spark ignition engines mostly use one injection system to deliver gasoline into the combustion chamber, using either direct injection or port fuel injection. Both technologies have their respective advantages. To integrate their advantages and to promote the use of renewable fuels, dual injection engines are in development in recent years. Dual injection represents an advanced combustion system and is a novel technology to address the urgent issues of sustainability and environmental protection. This study reviews the state-of-the-art research on dual injection spark ignition engines with a focus on renewable fuels, their advantages and engine performance. The main advantages of dual injection include greater control flexibility, enhanced cooling effect, knock mitigation, engine downsizing, extended lean-burn limits, higher thermal efficiency and reductions of several emission species. The most promising renewable fuels for dual injection are ethanol, methanol and hydrogen. Each renewable fuel is aimed at different advantages of dual injection. Alcohol-gasoline dual injection provides great anti-knock ability by taking advantage of alcohols' large enthalpies of vaporisation and high octane numbers, while hydrogen-gasoline dual injection provides extended lean-burn limits by taking advantage of hydrogen's low ignition energy, wide flammability limit and high flame speed. Direct injection of renewable fuels is the optimal injection strategy because it effectively utilises the strong cooling effect of alcohols or avoids the volumetric efficiency reduction and preignition of hydrogen. Dual injection generally demonstrates higher thermal efficiency than single injection. In addition, dual injection effectively reduces particulate emissions while there are usually trade-offs among gaseous emissions.
\end{abstract}

Keywords: Dual injection; Renewable fuels; Spark ignition engines; Thermal efficiency; Combustion; Emissions 


\section{Highlights}

- Dual injection provides great control flexibility by integrating advantages of DI and PFI.

- Alcohols and hydrogen enhance knock mitigation and lean-burn limits respectively.

- $\quad$ Renewables DI plus gasoline PFI is the optimal strategy for both alcohols and hydrogen.

- Dual injection increases thermal efficiency and reduces certain emission products.

- Dual injection is an effective and efficient technology to use renewable fuels in SI engines. 


\section{Abbreviations and symbols}

\begin{tabular}{|c|c|c|c|}
\hline $\mathrm{ABE}$ & Acetone-butanol-ethanol blend & LTC & Low temperature combustion \\
\hline AFR & Air fuel ratio & MBT & Minimum spark advance for best torque \\
\hline BTDC & Before top dead centre & NEDC & New European Driving Cycle \\
\hline $\mathrm{CDC}$ & Conventional diesel combustion & NMHC & Non-methane hydrocarbons \\
\hline CFD & Computational fluid dynamics & PEMS & Portable emission measurement system \\
\hline $\mathrm{CI}$ & Compression ignition & PFI & Port fuel injection \\
\hline DDFS & Direct dual fuel stratification & PM & Particulate matter \\
\hline DFSC & Dual fuel sequential combustion & PN & Particle number \\
\hline DI & Direct injection & RCCI & Reactivity controlled compression ignition \\
\hline DME & Dimethyl ether & RDE & Real driving emissions \\
\hline $\mathrm{DMF}$ & 2, 5-dimethylfuran & RON & Research octane number \\
\hline EGR & Exhaust gas recirculation & RVP & Reid vapour pressure \\
\hline $\begin{array}{l}\text { GDI/EDI/ } \\
\mathrm{MDI} / \mathrm{HDI}\end{array}$ & $\begin{array}{l}\text { Gasoline/ethanol/methanol/hydrogen } \\
\text { direct injection }\end{array}$ & SI & Spark ignition \\
\hline $\begin{array}{l}\text { GPI/EPI/ } \\
\text { MPI/HPI }\end{array}$ & $\begin{array}{l}\text { Gasoline/ethanol/methanol/hydrogen port } \\
\text { injection }\end{array}$ & THC & Total hydrocarbons \\
\hline ICCI & Intelligent charge combustion ignition & TWC & Three-way catalyst \\
\hline IMEP & Indicated mean effective pressure & WLTP & $\begin{array}{l}\text { Worldwide harmonised Light vehicle Test } \\
\text { Procedure }\end{array}$ \\
\hline KLST & Knock limited spark timing & WOT & Wide open throttle \\
\hline LHV & Lower heating value & $\lambda$ & Excess air ratio \\
\hline
\end{tabular}




\section{Introduction}

Modern economies rely heavily on the transport of goods and people, which are and will be largely powered by internal combustion engines in the next few decades [1-3]. The global numbers of cars and trucks were around 1.1 billion and 377 million in 2015, which are projected to reach 2.0 billion and 790 million in 2040, respectively [4]. Passenger cars are mostly (>80\%) powered by spark ignition (SI) engines worldwide, except for the European Union, India and South Korea markets where compression ignition (CI) engines have a significant share (39\%-52\%) [5, 6]. Rapid increases in the number of vehicles consume significant amounts of fossil fuels and emit a large percentage of total greenhouse gas emissions [7]. The International Energy Agency estimated that global energy consumption more than doubled during 1971 to 2015, and the percentage of energy use by the transport sector increased noticeably from $23 \%$ to $29 \%$ during the same period while other sectors mostly did not change [8]. Vehicle engines are also a major contributor to urban air pollution, posing a serious health hazard to the public $[9,10]$. A recent study estimated that vehicle tailpipe emissions caused 385000 premature deaths and US\$1 trillion of health damage worldwide in 2015 [11].

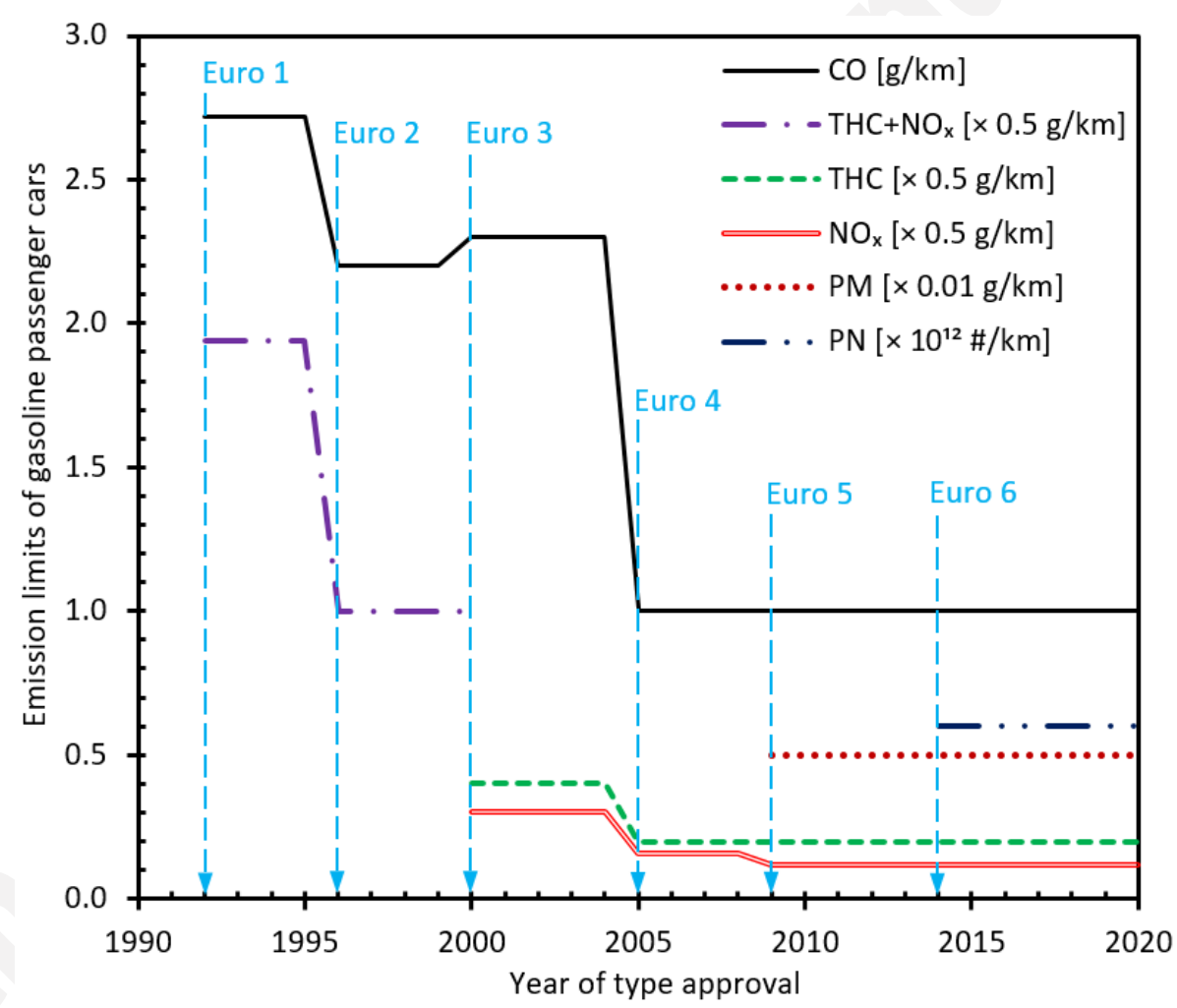

Fig. 1. Advancement of the European automotive emission standards for gasoline passenger cars. A non-methane hydrocarbons (NMHC) limit of $68 \mathrm{mg} / \mathrm{km}$ is introduced in addition to the total hydrocarbons (THC) limit since Euro 5 [12]. The particulate matter (PM) limit only applies to vehicles with DI engines and a limit of $4.5 \mathrm{mg} / \mathrm{km}$ is applied when using a revised measurement procedure (i.e. PMP) [12]. The particle number (PN) limit only applied to vehicles with DI engines and a limit of $6 \times 10^{12} \# / \mathrm{km}$ was used in the first three years of Euro 6 [13]. 
Regulations are becoming increasingly stringent to reduce both the air pollutant and greenhouse gas emissions. Fig. 1 demonstrates the advancement of emission limits for gasoline passenger cars from Euro 1 to 6 . The limit values have been reduced substantially and more pollutant species have been regulated during the past three decades. For instance, the $\mathrm{NO}_{\mathrm{x}}$ limit has been reduced by $60 \%$ from $0.15 \mathrm{~g} / \mathrm{km}$ in Euro 3 [14] to $0.06 \mathrm{~g} / \mathrm{km}$ in Euro 5 and 6 [12, 13]. Although the limit values are unchanged after Euro 5, the emission testing methods have become more stringent in Euro 6. Firstly, a Worldwide harmonised Light vehicles Test Procedure (WLTP) is introduced for type approval of new vehicles using chassis dynamometers, which is more representative of real-world driving than the outdated New European Driving Cycle (NEDC) $[15,16]$. In addition to the laboratory based WLTP, a Real Driving Emissions (RDE) test procedure has been introduced to measure vehicle emissions in the real world using a Portable Emission Measurement System (PEMS) [15]. The RDE test aims to reduce the significant discrepancy between the laboratory and real-world performance of emissions and fuel consumption [17, 18]. An initial conformity factor of 2.1 was used in 2017 , with the aim of reducing it to 1.0 as soon as possible and at the latest by 2023 [19]. Regarding regulations on greenhouse gas emissions, the European Union has tightened its fleet-wide average emission target from 130 $\mathrm{g} \mathrm{CO}_{2} / \mathrm{km}$ in 2015 to $95 \mathrm{~g} \mathrm{CO}_{2} / \mathrm{km}$ in 2021 which corresponds to a fuel consumption of $4.1 \mathrm{~L} / 100 \mathrm{~km}$ for gasoline cars [20].

To meet the ever stricter regulations on emissions and fuel economy, significant efforts have been taken to improve engine combustion system and to search for renewable fuels. For SI engines, it is critical for the fuel to mix with the intake air and form a suitable mixture before the electrical discharge from the spark plug is initiated. There are mainly three fuel injection technologies, namely carburettor, port fuel injection (PFI) and direct injection (DI) [21, 22]. PFI replaced carburettors in the 1980s due to its advantages in fuel saving via more precise control of fuel injection and emission reductions via exhaust after-treatment using a threeway catalyst (TWC). DI was developed in the 1990s and offers further advantages in fuel saving when compared with PFI. In spite of this, DI has not fully replaced PFI in modern SI engines. Table 1 shows the fuel injection technologies of the top 20 most popular car models in 2019 in Australia. As shown in Table 1, PFI and DI have similar market shares (14 vs 16 engine models) although DI is considered more advanced than PFI. This is because either of these two fuel injection technologies has its respective advantages and limitations, which will be discussed in detail in Section 3. This leads to a novel idea of using DI and PFI simultaneously in one engine (i.e. dual injection), which has the potential to integrate their advantages while avoiding their drawbacks. Dual injection offers greater flexibility in controlling mixture formation and combustion processes and is a promising technology to help achieve the ever stricter emissions and fuel efficiency standards. Dual injection has been in development in recent years and a few mass production cars have already adopted this concept, such as the Toyota RAV4, Toyota Camry and Volkswagen Golf. These vehicle models have shown advantages in engine downsizing (such as high compression ratios and turbocharging) and fuel economy compared with their competitors. In these dual injection engines, the same fuel (i.e. gasoline) is used for both PFI and DI. 
Table 1. Engine specifications of the top 20 most popular gasoline cars in Australia in 2019.

\begin{tabular}{|c|c|c|c|c|c|c|c|c|}
\hline \multirow[b]{2}{*}{ No. } & \multirow[b]{2}{*}{ Car model } & \multirow[b]{2}{*}{ Sales* } & \multicolumn{6}{|c|}{ Engine specifications $\uparrow$} \\
\hline & & & $\begin{array}{l}\text { Engine model } \\
\text { code }\end{array}$ & $\begin{array}{l}\text { Displacement } \\
\text { (L) }\end{array}$ & $\begin{array}{l}\text { Air intake } \\
\text { system }\end{array}$ & $\begin{array}{l}\text { Injection } \\
\text { system }\end{array}$ & $\begin{array}{l}\text { Compression } \\
\text { ratio }\end{array}$ & $\begin{array}{l}\text { Fuel consumption } \\
(\mathrm{L} / 100 \mathrm{~km})\end{array}$ \\
\hline 1 & Toyota Hilux & 47649 & 2TR-FE & 2.7 & Aspirated & PFI & $10.2: 1$ & $10.4-11.1$ \\
\hline 2 & Ford Ranger & 40690 & \multicolumn{6}{|c|}{ No petrol model is available } \\
\hline \multirow{3}{*}{3} & \multirow{3}{*}{ Toyota Corolla } & \multirow{3}{*}{30468} & 2ZR-FE & 1.8 & Aspirated & PFI & 10.0:1 & $6.4-6.8$ \\
\hline & & & 2ZR-FXE & 1.8 & Aspirated & PFI & 13.0:1 & 3.5-4.2 (hybrid) \\
\hline & & & M20A-FKS & 2.0 & Aspirated & DI & 13.0:1 & $6.0-6.5$ \\
\hline \multirow{3}{*}{4} & \multirow{3}{*}{ Hyundai i30 } & \multirow{3}{*}{28378} & Gamma & 1.6 & Turbocharged & DI & $9.5: 1$ & 7.1-7.5 \\
\hline & & & $\mathrm{Nu}$ & 2.0 & Aspirated & DI & $11.5: 1$ & 7.3-7.4 \\
\hline & & & G4KH & 2.0 & Turbocharged & DI & $9.5: 1$ & 8.0 \\
\hline 5 & Mitsubishi Triton & 25819 & 4G64 & 2.4 & Aspirated & PFI & $9.0: 1$ & 11.4 \\
\hline \multirow{3}{*}{6} & \multirow{3}{*}{ Mazda CX-5 } & \multirow{3}{*}{25539} & PE-VPS & 2.0 & Aspirated & DI & $13.0: 1$ & 6.9 \\
\hline & & & PY-VPR & 2.5 & Aspirated & DI & 13.0:1 & 7.4 \\
\hline & & & PY-VPR & 2.5 & Turbocharged & DI & $10.5: 1$ & 8.2 \\
\hline \multirow{2}{*}{7} & \multirow{2}{*}{ Mazda 3} & \multirow{2}{*}{24939} & PE-VPS & 2.0 & Aspirated & DI & 13.0:1 & $5.7-6.4$ \\
\hline & & & PY-VPS & 2.5 & Aspirated & DI & 13.0:1 & $6.0-6.6$ \\
\hline \multirow{3}{*}{8} & \multirow{3}{*}{ Toyota RAV4 } & \multirow{3}{*}{24260} & M20A-FKS & 2.0 & Aspirated & $\mathrm{DI}+\mathrm{PFI}$ & 13.0:1 & $6.5-6.8$ \\
\hline & & & A25A-FKS & 2.5 & Aspirated & $\mathrm{DI}+\mathrm{PFI}$ & 13.0:1 & 7.3 \\
\hline & & & A25A-FXS & 2.5 & Aspirated & $\mathrm{DI}+\mathrm{PFI}$ & $14.0: 1$ & 4.7-4.8 (hybrid) \\
\hline \multirow{2}{*}{9} & \multirow{2}{*}{ Kia Cerato } & \multirow{2}{*}{21757} & G4NA & 2.0 & Aspirated & PFI & $10.3: 1$ & 7.4-7.6 \\
\hline & & & G4FJ & 1.6 & Turbocharged & DI & 10.0:1 & 6.8 \\
\hline 10 & Mitoubichi A CY & 20006 & $4 \mathrm{~B} 11$ & 2.0 & Aspirated & PFI & $10.0: 1$ & 7.6-7.7 \\
\hline 10 & 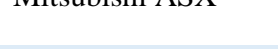 & 20000 & $4 \mathrm{~B} 12$ & 2.4 & Aspirated & PFI & $10.5: 1$ & 7.9 \\
\hline 11 & Nicsan X Trail & 10726 & MR20DD & 2.0 & Aspirated & DI & $11.2: 1$ & 8.2 \\
\hline 11 & Nissan A- & 19120 & QR25DE & 2.5 & Aspirated & PFI & 10.0:1 & $7.9-8.3$ \\
\hline 12 & Toyota Landcruiser & 18335 & 1UR-FE & 4.6 & Aspirated & PFI & $10.2: 1$ & 13.4 \\
\hline 13 & Hyundai Tucson & 18251 & T-GDI & 1.6 & Turbocharged & DI & $10.1: 1$ & 7.7 \\
\hline 15 & пуйdal tucsoll & $102 J 1$ & $2.0 \mathrm{GDI}$ & 2.0 & Aspirated & DI & $11.5: 1$ & 7.8-7.9 \\
\hline & & & 4J11 MIVEC & 2.0 & Aspirated & PFI & $10.5: 1$ & 7.0 \\
\hline 14 & Mitcubichi Outlanda & r 17514 & 4B11 MIVEC & 2.0 & Aspirated & PFI & - & 1.7 (plug-in hybrid) \\
\hline 14 & 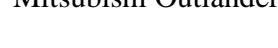 & 111714 & 4J12 MIVEC & 2.4 & Aspirated & PFI & $10.5: 1$ & 7.2 \\
\hline & & & 4B12 MIVEC & 2.4 & Aspirated & PFI & $12.0: 1$ & 1.9 (plug-in hybrid) \\
\hline 15 & Holden Colorado & 17472 & No petrol model & is available & & & & \\
\hline 16 & Isuzu D-Max & 16892 & No petrol model & is available & & & & \\
\hline & & & 2AR-FE & 2.5 & Aspirated & PFI & $10.4: 1$ & $7.8-8.3$ \\
\hline 17 & Toyota Camry & 16768 & A25A-FXS & 2.5 & Aspirated & $\mathrm{DI}+\mathrm{PFI}$ & $14.0: 1$ & 4.2-4.5 (hybrid) \\
\hline & & & 2GR-FKS & 3.5 & Aspirated & $\mathrm{DI}+\mathrm{PFI}$ & $11.8: 1$ & $8.7-8.9$ \\
\hline 18 & Subaro Forecter & 15096 & e-Boxer & 2.0 & Aspirated & DI & $12.5: 1$ & 6.7 (hybrid) \\
\hline 10 & Suodiu rorester & 15090 & FB25 & 2.5 & Aspirated & DI & 12.0:1 & 7.4 \\
\hline 19 & Mazda CX-3 & 14813 & SKYACTIV-G & 2.0 & Aspirated & DI & 13.0:1 & $6.3-6.7$ \\
\hline & & & CZDA & 1.4 & Turbocharged & DI & $10.0: 1$ & $5.4-5.7$ \\
\hline 20 & Voll-runon $\mathrm{Golf}$ & 14255 & CJSB & 1.8 & Turbocharged & $\mathrm{DI}+\mathrm{PFI}$ & $9.6: 1$ & 6.8 \\
\hline 20 & vikswageril Uon & $14 J 3 J$ & DJHB & 2.0 & Turbocharged & $\mathrm{DI}+\mathrm{PFI}$ & $9.3: 1$ & $7.2-7.3$ \\
\hline & & & CHHA & 2.0 & Turbocharged & $\mathrm{DI}+\mathrm{PFI}$ & $9.6: 1$ & 6.5 \\
\hline
\end{tabular}

* The 2019 new car sales were from the Federal Chamber of Automotive Industries at https://www.caradvice.com.au/817278/vfacts2019-new-car-sales-results <accessed 23.04.2020>

† The engine specifications of 2019 car models were from https://www.redbook.com.au/ 〈accessed 23.04.2020〉 
The potential of dual injection in fuel saving and emissions reduction can be further enhanced when combined with renewable fuels by taking advantage of their fuel properties (Table 2), such as high octane number, increased cooling effect and wide flammability limit which will be discussed in Section 4. Renewable fuels are becoming increasingly important in combating global warming and fossil fuel depletion, among which ethanol is the most widely used alternative fuel for SI engines [23-25]. Currently, it is usually used by blending with gasoline (e.g. E10) to partially substitute fossil fuel due to its limited supply and compatibility with existing engines. However, blending renewable fuels with gasoline at fixed ratios would not achieve an optimal performance over the wide engine operating conditions. Thus the in-cylinder blending of gasoline and renewable fuels in the dual injection concept provides the flexibility to utilise renewable fuels more effectively and efficiently than pre-blending. Dual injection has great potential in improving the combustion performance of SI engines by changing the blending ratio and injection strategy according to the operating condition.

The dual injection concept is not new and has been investigated extensively in CI engines. Two dual injection configurations have been widely explored in CI engines, namely DI+PFI and DI+DI. Depending on the proportion of premixed fuel, dual injection CI engines can work in low temperature combustion (LTC) or conventional diesel combustion (CDC) mode, where LTC behaves more like a premixed flame while CDC behaves more like a diffusion flame. DI+PFI is usually studied in LTC mode such as reactivity controlled compression ignition (RCCI) [26-31] and dual fuel sequential combustion (DFSC) [32, 33], although it also works in CDC mode such as natural gas/hydrogen/alcohols PFI + diesel DI [34-36]. Meanwhile, DI+DI is studied in both LTC (e.g. intelligent charge combustion ignition (ICCI) [37, 38] and direct dual fuel stratification (DDFS) [39, 40]) and CDC (e.g. hydrogen-diesel [41] and methanol-diesel [42] dual DI) modes. When it comes to SI engines, however, dual injection is a relatively new concept and has attracted great attention in recent years. So far there is a lack of critical review in this area.

This paper aims to review the recent progress in dual injection of gasoline and renewable fuels in SI engines. The dual injection concept here specifically refers to the combination of DI and PFI which has attracted the most research attention, although there are a few studies on dual PFI [43-49] and dual DI [50, 51]. This paper is organised as follows. Firstly, the properties, benefits and challenges of the key suitable renewable fuels for dual injection SI engines are introduced. Then the mechanisms, advantages and disadvantages of DI and PFI are examined. Following that, the main advantages of dual injection concept in integrating DI and PFI's advantages and promoting the use of renewable fuels in SI engines are discussed. Finally, the combustion and emissions performance of various dual injection SI engines are reviewed.

\section{Renewable fuels for SI engines}

Properties of renewable fuels that are compatible with the dual injection concept in SI engines are compared with gasoline in Table 2. The alternative fuels proposed can be broadly broken into gaseous fuels, alcohols, oxygenates and furans. All of these alternative fuels have been thoroughly investigated in 
automotive applications, with the exception of furans which have more recently attracted research attention due to the development of catalytic processes that may lead to scalable production capacity from biomass [52, 53]. Although the production of several of these fuels could be achieved with fossil fuels such as coal and oil, in this work we wish to emphasise the opportunity that exists with producing all of these alternative fuels renewably. In Table 2, we also overview a range of parameters that will determine the performance of each fuel in an SI engine application. This includes both chemical and physical properties that will dictate the charge cooling effect, volatility, spray, ignition and combustion dynamics.

Out of the many fuel properties that dictate SI engine performance, arguably, the most important two are the research octane number (RON) and volatility characteristics. RON captures the knock resistance of a fuel, with higher values enabling the engine to run with a higher compression ratio which improves power output and thermal efficiency. As shown in Table 2, all renewable fuels exhibit a larger RON than gasoline. Out of these fuels, hydrogen has the highest RON by a considerable margin. The driveability of a vehicle is influenced by a fuel's volatility which is partially captured by the Reid vapour pressure (RVP). The renewable fuels overviewed in Table 2 vary widely in RVP, with higher alcohols having the lowest RVP and gaseous fuels showing the highest RVP. Apart from the central importance of RON and RVP, several other fuel properties are essential for good combustion performance.

From an emissions perspective, one of the key benefits of fuels containing oxygen (such as alcohols, ethers and furans) is their demonstrated role in reducing $\mathrm{CO}$ and $\mathrm{HC}$ emissions. Despite this, oxygenated fuels have reduced lower heating values (LHV) which can be considered a disadvantage. On the other hand, furans have energy densities that are more comparable with gasoline and generally have fuel properties that are quite similar, making them a fuel type with great "drop in" potential in SI engines. Oxygenated fuels such as alcohols also have higher enthalpies of vaporisation which can increase the charge cooling effect and intake air density. The charge cooling effect also plays a role in reducing the flame temperature which leads to $\mathrm{NO}_{\mathrm{x}}$ reduction. On the contrary, the lower RVP and higher enthalpy of vaporisation of alcohols can lead to engine cold start issues.

In terms of fuel chemical composition, the only carbon free fuel is hydrogen. Benefits of using hydrogen as a transport fuel include its increased LHV, wide flammability limit, and its considerable RON. Owing to its wide flammability limit, hydrogen mixtures can be combusted in an overly lean manner for improved thermal efficiency compared to the stoichiometric mixtures usually applied in SI engines. In spite of these advantages, there are safety matters to consider such as invisible flames during the combustion process and the possibility of flashback into the intake port due to hydrogen's high laminar flame velocity. 
Table 2. Physico-chemical properties of renewable fuels and gasoline that are compatible with the dual injection concept in SI engines.

\begin{tabular}{|c|c|c|c|c|c|c|c|c|c|c|c|}
\hline Properties & Gasoline & Hydrogen & Methanol & Ethanol & Iso-Butanol & n-Butanol & Methane & MTBE & ETBE & MF & DMF \\
\hline Chemical formula & $\sim \mathrm{C}_{4}-\mathrm{C}_{12}$ & $\mathrm{H}_{2}$ & $\mathrm{CH}_{3} \mathrm{OH}$ & $\mathrm{C}_{2} \mathrm{H}_{5} \mathrm{OH}$ & $\mathrm{C}_{4} \mathrm{H}_{9} \mathrm{OH}$ & $\mathrm{C}_{4} \mathrm{H}_{9} \mathrm{OH}$ & $\mathrm{CH}_{4}$ & $\mathrm{C}_{5} \mathrm{H}_{12} \mathrm{O}$ & $\mathrm{C}_{6} \mathrm{H}_{14} \mathrm{O}$ & $\mathrm{C}_{5} \mathrm{H}_{6} \mathrm{O}$ & $\mathrm{C}_{6} \mathrm{H}_{8} \mathrm{O}$ \\
\hline Molar mass (g/mol) & $58-170$ & 2 & 32 & 46 & 74 & 74 & 16 & 88 & 102 & 82 & 96 \\
\hline $\mathrm{H} / \mathrm{C}$ ratio & $1.7-1.9$ & Carbon free & 4 & 3 & 2.5 & 2.5 & 4 & 2.4 & 2.33 & 1.2 & 1.33 \\
\hline Oxygen content (\%w) & 0 & 0 & 50 & 34.8 & 21.6 & 21.6 & 0 & 18.2 & 15.7 & 19.5 & 16.7 \\
\hline Density @20 ${ }^{\circ} \mathrm{C}\left(\mathrm{g} / \mathrm{cm}^{3}\right)$ & $0.72-0.78$ & $0.0013 *[54]$ & 0.796 & 0.798 & 0.801 & 0.810 & $0.72^{[55]}$ & 0.735 & 0.742 & 0.913 & 0.890 \\
\hline $\begin{array}{c}\text { Dynamic viscosity } \\
(\mathrm{mPa} \cdot \mathrm{s})\end{array}$ & $0.37-0.44$ & $0.009^{[54]}$ & 0.6 & 1.5 & 8.3 & 3.6 & $0.01^{[54]}$ & 0.31 & 0.53 & 0.4 & 0.53 \\
\hline Boiling point $\left({ }^{\circ} \mathrm{C}\right)$ & $25-210$ & $-253^{[54]}$ & 65 & 78 & 108 & 118 & $-162^{[54]}$ & 55 & 73 & 65 & 92 \\
\hline $\begin{array}{l}\text { Auto-ignition } \\
\text { temperature }\left({ }^{\circ} \mathrm{C}\right)\end{array}$ & 257 & $572^{[56]}$ & 385 & 363 & 415 & 343 & $540^{[54]}$ & 374 & 375 & 450 & $286^{[57]}$ \\
\hline Ignition energy $(\mathrm{mJ})$ & $0.25^{[56]}$ & $0.018^{[58]}$ & $0.14^{[58]}$ & $0.23^{[59]}$ & NA & $0.6^{[60]}$ & $0.28^{[58]}$ & NA & NA & $0.225^{\wedge[60]}$ & NA \\
\hline $\mathrm{RVP} @ 37^{\circ} \mathrm{C}(\mathrm{kPa})$ & $54-103$ & NA & 32 & 16 & 3.3 & 2.2 & NA & 32 & 30 & $18.5^{[61]}$ & $13.4^{[61]}$ \\
\hline LHV (MJ/kg) & $41-44$ & $120^{[54]}$ & 19.7 & 26.8 & 33.1 & 33.2 & $50^{[55]}$ & 38.2 & 36 & 31.2 & 32.9 \\
\hline $\begin{array}{l}\text { Enthalpy of vaporisation } \\
\qquad(\mathrm{kJ} / \mathrm{kg})\end{array}$ & 373 & $448^{[54]}$ & 1110 & 912 & 566 & 584 & $510^{[54]}$ & 340 & 323 & 358 & 332 \\
\hline RON & 88-98 & $120-140^{[55]}$ & 109 & 109 & 105 & 98 & $120^{[55]}$ & 117 & 118 & 103 & 101 \\
\hline Flammability limits (\%) & $1.4-7.6^{[54]}$ & $4-75^{[54]}$ & $7.3-36^{[54]}$ & $4.3-19^{[54]}$ & $1.2-10.9^{[62]}$ & $1.4-11.2^{[62]}$ & $5-15^{[54]}$ & $1.5-8.5^{[63]}$ & $1.2-7.7^{[64]}$ & $1.9-14^{[65]}$ & NA \\
\hline Stoichiometric AFR & 14.7 & $34.3^{[54]}$ & 6.4 & 9 & 11.1 & 11.1 & $17.2^{[55]}$ & 11.7 & 12.2 & 10.1 & 10.7 \\
\hline $\begin{array}{l}\text { Laminar flame speed } \\
\qquad(\mathrm{m} / \mathrm{s})\end{array}$ & $0.37-0.43^{[66]}$ & $1.85^{[66]}$ & $0.56^{[67]}$ & $0.39^{[66]}$ & $0.45^{[68]}$ & $0.48^{[68]}$ & $0.38^{[66]}$ & $0.35^{[69]}$ & $0.30^{[70]}$ & $0.47^{[71]}$ & $0.38^{[72]}$ \\
\hline $\begin{array}{c}\text { Adiabatic flame } \\
\text { temperature @ } 1 \text { bar, } \\
20{ }^{\circ} \mathrm{C}, \lambda=1\end{array}$ & 2346 & $2377^{[73]}$ & 2216 & 2310 & 2372 & 2388 & $2222^{[73]}$ & 2623 & 2399 & 2535 & 2509 \\
\hline
\end{tabular}

Notes: MTBE, methyl tert-butyl ether; ETBE, ethyl tert-butyl ether; DMF: 2,5-dimethylfuran; MF, 2-methylfuran; NA, not applicable/available; * @ 15 ${ }^{\circ}$; ${ }^{\wedge}$ Furan;

All remaining data are from [74]. 


\section{Fuel injection technologies of SI engines}

Fuel injection systems of modern SI engines are dominated by DI and PFI, as shown in Table 1. In a PFI system (Fig. 2a), fuel is metered by a nozzle and sprayed into the intake manifold, which is carried into cylinders by the intake air [75]. There are two types of PFI, namely single- and multi-point injection. Singlepoint injection (e.g. throttle body injection) injects fuel at the main intake manifold which serves all the cylinders, while multi-point injection injects fuel at the back of intake valve(s) of each cylinder. Multi-point injection distributes fuel more evenly and precisely among cylinders than single-point injection, and thus is the dominant type in modern PFI engines. In a DI system (Fig. 2b), fuel is sprayed into the engine combustion chamber directly via a high pressure injector. DI engines are designed in two combustion modes, namely homogeneous stoichiometric combustion and stratified lean combustion [76]. The homogeneous mode injects fuel during early intake stroke to form a homogenous stoichiometric mixture by the time of spark discharge. The stratified mode injects fuel later to form an ignitable mixture in the regions around the spark plug but a lean mixture in other regions, which can be realised by either a wall-, air- or spray-guided mixing process. Although the stratified mode has higher fuel efficiency, the conversion efficiency of the TWC is low. As a result, current DI engines mostly adopt the homogenous stoichiometric combustion mode.

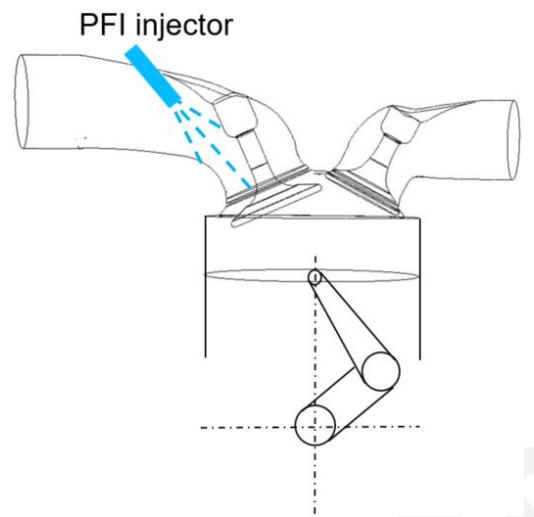

(a)

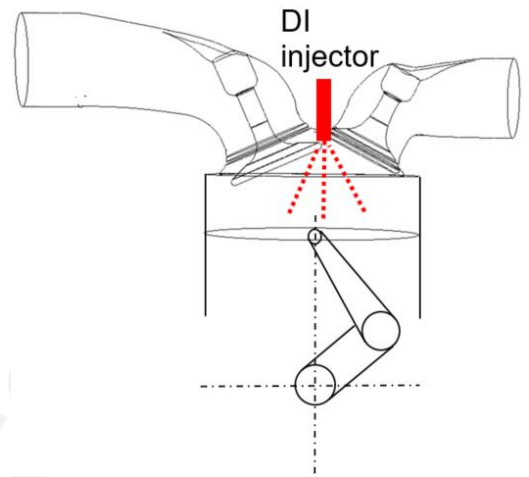

(b)

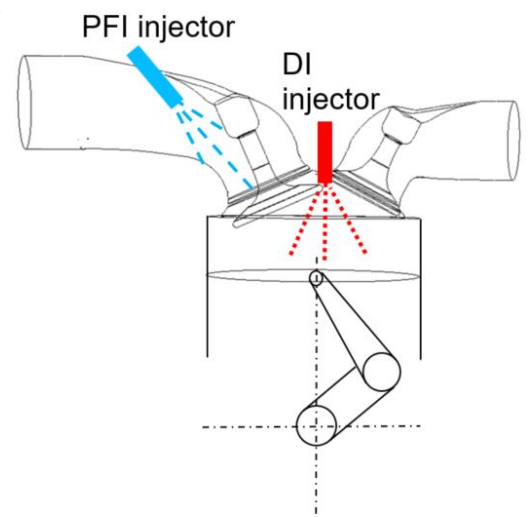

(c)

Fig. 2. Schematics of PFI (a), DI (b) and dual injection (c) systems.

Table 3 compares the advantages and disadvantages of PFI and DI systems [22, 76, 77]. PFI usually starts injection before the intake valves open and fuel films are formed on the surfaces of intake ports and valves. The liquid fuel absorbs heat from the hot surfaces and evaporates partially before being entrained into the engine combustion chamber by the intake air. Therefore, PFI engines have sufficient time for fuel evaporation and mixing, and low pressure injection (of a few bar) is applied. The homogenous stoichiometric combustion of PFI engines ensures a high TWC conversion efficiency. In addition, the good evaporation and mixing processes reduce the formation of particulate emissions. On the other hand, port wall wetting causes a time lag between the injection and fuel delivery into cylinders, leading to metering errors and slow transient responses. Particularly, over-fuelling is required for cold start when intake port is cold, which results in worsened fuel economy and increased $\mathrm{HC}$ emissions. 
DI engines inject fuel directly into each cylinder, therefore time lag is eliminated and transient response is improved. Fuel evaporation inside the combustion chamber cools the air, which increases volumetric efficiency and reduces knock propensity. Thus a higher compression ratio can be achieved to increase the thermal efficiency. DI technology also offers an extended exhaust gas recirculation (EGR) tolerance limit and enhanced potential for system optimisation [22]. However, all these benefits come at a cost. Since the time allowed for fuel evaporation and mixing is reduced, high pressure injection (up to $20 \mathrm{MPa}$ ) is required to generate fine spray droplets. High pressure fuel injection and mixture formation have higher control complexity over a wide engine operating range, and fuel impingement may occur on the cylinder and piston walls. Unevaporated liquid fuel droplets by spark timing will participate in diffusion burning and thus produce high particulate emissions like diesel engines. Saliba et al. [78] investigated the gaseous and particulate emissions performance of 15 DI and 67 PFI light-duty petrol vehicles. The results demonstrated insignificant difference of regulated gaseous emissions between PFI and DI vehicles. However, the particulate emissions of DI vehicles were higher by a factor of two than PFI vehicles. Higher particulate emissions of DI engines were also reported in [79-83] which tested smaller sample sizes. The latest emission regulations such as Euro 6 and China 6 have enforced PM and PN limits, and thus DI engines will need to adopt gasoline particulate filters to meet the new regulations $[84,85]$. Finally, injector deposits and ignition fouling are also challenges in DI engines. Injector deposits are formed due to the exposure to high-temperature combustion environment, which can reduce injector fuel flow rates and alter the designed spray characteristics [86]. Ignition fouling is caused by fuel impingement on the electrodes of spark plug due to the close spacing between injector and spark plug [22].

Table 3. Comparison of advantages and disadvantages between PFI and DI technologies.

\begin{tabular}{lll}
\hline & PFI & DI \\
\hline Advantages & Long time for fuel evaporation and mixing & Improved transient response \\
& Low cost of low pressure injection system & High compression ratio and fuel efficiency \\
& Low gaseous emissions with TWC & Low HC during cold start \\
& Low PM and PN emissions & Extended EGR tolerance limit \\
Disadvantages & Fuel delivery delay due to port wall wetting & Enhanced potential for system optimisation \\
& Low compression ratio and fuel efficiency & High cost of high pressure injection system \\
& Fuel evaporation in intake port reduces volumetric Reduced TWC efficiency under lean mode \\
& efficiency & High PM and PN emissions \\
& Over fuelling and high HC during cold start & In-cylinder fuel impingement \\
& & Injector deposits and ignition fouling \\
\hline
\end{tabular}

\section{Advantages of dual injection}

As discussed above, both DI and PFI have their respective advantages. DI+PFI dual injection (Fig. 2c) is a novel concept to integrate their advantages. Dual injection concept offers greater flexibility in the control of mixture formation and combustion processes. It is also a more effective and efficient method to use the limited supply of renewable fuels than blending them with gasoline at fixed ratios. In addition, the use of 
renewable fuels can further enhance the benefits of dual injection by taking advantage of their fuel properties such as higher enthalpy of vaporisation, greater octane number and wider flammability limit. Specifically, dual injection provides the following advantages when compared with DI or PFI.

\subsection{Control flexibility}

Dual injection enables an engine to switch between PFI, DI and dual injection modes to achieve optimal performance under various operating conditions. For example, DI can be used for engine cold start to avoid over-fuelling of PFI and thus to improve the fuel efficiency and HC emissions. Under low load conditions, the engine can work in PFI mode to avoid fuel impingement and poor evaporation of DI due to the lowpressure and low-temperature in-cylinder environment. Dual injection has also been proposed to address the issue of high particulate emissions under cold-start and transient conditions since a large fraction of particulate emissions are generated at these times in a test cycle [87, 88]. As engine load increases, the percentage of DI fuel can be increased to cool the combustion temperature and thus to suppress engine knock. Moreover, the anti-knock ability can be greatly enhanced by using fuels with high RON and/or large enthalpy of vaporisation (such as ethanol and premium unleaded petrol). Such a strategy is often referred to as octaneon-demand [89-92] and several patents have been granted using this idea [93-97].

Dual injection can also change the renewable fuel and gasoline blending ratio in real time according to the operating condition. Experiments showed that different biofuel-gasoline blending ratios were needed to achieve an optimal engine performance under different operating conditions [43, 98-102]. The supply of renewables is limited and can only partially substitute gasoline fuel. Thus dual injection enables an ondemand control of in-cylinder blending ratio, which is a more effective and efficient use of renewable fuels than pre-blending them with gasoline at a fixed ratio. Daniel et al. [103, 104] compared the combustion performance of gasoline-biofuel dual injection with DI of gasoline-biofuel blends. The results showed advantages of dual injection over DI, including a shorter combustion duration, greater in-cylinder pressure and higher thermal efficiency, and reduced $\mathrm{CO}$ and mean PM diameter.

\subsection{Enhanced cooling effect}

DI has stronger cooling effect than PFI because of fuel evaporation inside the engine combustion chamber. Such cooling effect brings various benefits to SI engines, including higher volumetric efficiency, lower $\mathrm{NO}_{\mathrm{x}}$ emissions, reduced knock propensity, larger compression ratio, greater turbocharging and higher thermal efficiency. Moreover, the cooling effect of DI could be further strengthened by using fuels with larger enthalpies of vaporisation. Table 2 shows that the enthalpies of vaporisation of alcohol fuels, in particular ethanol and methanol, are much larger than gasoline. Therefore, existing dual injection studies mostly used gasoline for PFI and alcohols for DI. 
The cooling effect of DI can be quantified in various ways. The simplest way is to directly measure the air temperature inside the cylinders. Cold-wire resistance thermometers were applied to measure the incylinder air temperatures of PFI and DI engines [105, 106], which required fast-response and thin sensors due to the highly transient nature of in-cylinder flows. As a result, such experiments were only conducted under non-firing conditions to protect the fragile sensors [105, 106]. Attar et al. [107] developed a tracerbased PLIF method to measure the in-cylinder gas temperature of a DI engine under both motoring and firing conditions. So far, the majority of experimental studies quantified the cooling effect indirectly by measuring parameters that linked to charge cooling, such as in-cylinder pressures [108], volumetric efficiencies [109] and anti-knock effects [110,111]. Wu et al. [112] measured the volumetric air flow rate of a gasoline PFI plus gasoline/DMF/ethanol DI engine. They found that air flow rate increased with the DI ratio and the increase was much bigger for ethanol than DMF and gasoline. Zhuang and Hong [113, 114] found that the volumetric efficiency of a gasoline PFI plus ethanol DI engine increased with the DI ratio only when the injection was during intake valve open. However, volumetric efficiency or intake flow rate could only reflect a proportion of the charge cooling effect that occurred before the intake valves are closed. In a DI SI engine, fuel evaporation would continue during the compression stoke or even the combustion process. Therefore, knock onset was considered a better parameter to quantify the cooling effect. It is worth mentioning that the anti-knock ability of DI can come from two parts, namely the thermal benefit (i.e. cooling effect) and chemical benefit (i.e. higher RON). It was found that the benefit of ethanol's cooling effect was comparable to its higher RON $[111,115]$. To quantitatively compare ethanol's thermal and chemical benefits, an increase of $2-8 \mathrm{~kJ} / \mathrm{kg}$ in the mixture cooling power is equivalent to one-point increase in the RON [116], or adding $10 \%$ ethanol into gasoline increases the RON by five points [117].

Meanwhile, numerical simulation is an economic and powerful tool to overcome the challenges of experimental methods and has been adopted to quantify the cooling effect of DI and dual injection systems. Wyszynski et al. [109] used a 0-D model to estimate the theoretical increases in volumetric efficiency of DI over PFI. Kasseris and Heywood [111] used an 1-D model to evaluate the anti-knock benefits of a DI engine fuelled with ethanol-gasoline blends [111]. However, 0-D and 1-D models were for specific aims and thus the output information was usually very limited. Huang et al. [102] used a 3-D computational fluid dynamics (CFD) model to investigate the cooling effect of a gasoline PFI plus ethanol DI dual injection engine. They found that the overall cooling effect increased with DI ratio within 0\%-58\% but not with higher DI ratios, due to ethanol's low evaporation rate and in-cylinder wall wetting. Ethanol evaporates relatively slowly when compared with gasoline under low-temperature conditions (such as naturally-aspirated engines) [118, 119], which limits the amount of the realised cooling effect from ethanol. This can be improved by increasing the air temperature. Kasseris and Heywood [110] explored the effect of intake air temperature on cooling effect by 3-D CFD modelling. They found that all the theoretical cooling effect could be realized under a high intake air temperature condition of $120^{\circ} \mathrm{C}$. 


\subsection{Knock mitigation}

The anti-knock ability of a fuel is described by RON in SI engines. Table $\mathbf{2}$ shows that renewable fuels all have higher RON than gasoline. In addition, dual injection of gasoline and alcohol fuels can further enhance the anti-knock ability by taking advantage of the cooling effect of DI and the higher enthalpies of vaporisation of alcohols. As discussed above, the thermal and chemical benefits have the same level of importance in knock mitigation $[111,115]$. The advantages of dual injection in knock mitigation have been extensively investigated by engine experiments. Liu et al. [120] investigated the knock characteristics of a methanol PFI plus gasoline DI engine and reported that dual injection could effectively suppress engine knock, extend high-load limit and improve fuel economy. Experiments on an ethanol PFI plus gasoline DI engine showed simultaneous reductions of knock propensity and emissions when ethanol was injected during intake valve open [121]. Meanwhile, Zhuang et al. [122] evaluated the knock mitigation ability of a gasoline PFI plus ethanol DI engine. They found that dual injection effectively reduced knock by increasing the ethanol DI ratio, and permitted a more advanced spark timing and higher intake air pressure when compared with gasoline PFI or DI. However, experiments on a gasoline PFI plus n-butanol DI engine showed that dual injection of 20\% and 50\% n-butanol had a higher knock propensity and intensity than gasoline PFI, although dual injection demonstrated a higher indicated mean effective pressure (IMEP) [123]. A comparison between the results in [123] and [120-122] clearly demonstrates that biofuels (e.g. ethanol and methanol) with higher enthalpies of vaporisation and larger RON will have greater anti-knock ability.

\subsection{Engine downsizing}

Engine downsizing is considered a key technology to achieve future carbon reduction targets [124, 125]. The concept of engine downsizing is to use a smaller engine in a car to provide similar power performance to a larger engine by boosting with a turbocharger while keeping the compression ratio as high as possible to achieve the best thermal efficiency. The main advantages of engine downsizing include lower mechanical and thermal losses, reduced engine weight, and more operation time within the optimal performance zone of an engine [125]. Turner et al. [126] demonstrated that it was possible to reduce engine displacement by $60 \%$ and fuel consumption by $35 \%$, while still achieve a comparable torque performance of a modern large (e.g. $5.0 \mathrm{~L}$ ) naturally-aspirated engine. However, the key challenges of downsizing of SI engines are the increased knock propensity at high load and reduced fuel economy at part load [124]. The greater control flexibility and anti-knock ability of dual injection could help address these challenges. As shown in Table 1, by applying dual injection, the Toyota M20A-FKS/A25A-FKS/A25A-FXS naturally-aspirated engines have achieved high compression ratios of 14:1 in a hybrid configuration and 13:1 in a conventional configuration in mass production cars (i.e. Camry and RAV4 models). The Volkswagen CJSB/DJHB/CHHA turbocharged engines have also adopted dual injection systems. It should be pointed out that the same fuel (i.e. gasoline) is used for both PFI and DI in these dual injection engines. It is expected that more aggressive engine downsizing (e.g. higher turbocharging, larger compression ratio and more spark advance) could be adopted by using renewable fuels with the dual injection concept due to their greater RON and enthalpies of vaporisation. 


\subsection{Fast combustion speed}

Renewable fuels mostly have higher flame speeds than gasoline. Therefore, adding renewable fuels into gasoline engines could enhance the burning rate. Most studies have observed faster combustion speeds of dual injection systems either indirectly via in-cylinder pressure related parameters or directly via visualisation of in-cylinder flows by experimental and numerical methods. For example, experiments on engines equipped with gasoline PFI plus biofuels DI [112, 113], alcohols PFI plus gasoline DI [127] and gasoline PFI plus hydrogen DI [128] dual injection systems all reported faster combustion speeds with shorter/earlier combustion durations/phases (e.g. 0-10\%, 10\%-90\% and 50\% of mass fraction burnt), higher/earlier phase of peak in-cylinder pressure, or higher/earlier phase of peak heat release rate. Jiang et al. [129] visualised the combustion process in a gasoline PFI plus ethanol/DMF DI optical engine and found that both gasolineethanol and gasoline-DMF dual injection systems had faster combustion speeds than gasoline PFI. CFD modelling results of a gasoline PFI plus ethanol DI engine also showed higher flame propagation speed of dual injection than gasoline PFI when the ethanol ratio was less than $76 \%[102,130]$.

\subsection{Extended lean burn limit}

Lean burn technology is an effective strategy to reduce fuel consumption and $\mathrm{NO}_{\mathrm{x}}$ emissions of SI engines due to lower pumping losses and combustion temperatures [131, 132]. However, the application of lean burn technology is limited by the issues of higher cyclic variation, lower combustion speed and higher ignition energy. Dual injection of renewable fuels offers the potential to extend the lean burn limit. In particular, hydrogen has significantly higher flame velocity, wider flammability limit, lower ignition energy and faster diffusion rate than gasoline [133], and thus has been extensively investigated for extending the lean burn limit of SI engines. Experiments on a gasoline PFI plus hydrogen DI engine showed that hydrogen addition increased thermal efficiency and reduced cyclic variation under lean conditions $[128,134,135]$. The lean burn limit increased with hydrogen DI ratio and could reach an excess air ratio $(\lambda)$ of 2.65 with $10.5 \%$ of hydrogen [134]. Hydrogen addition could also extend the EGR limit under lean-burn conditions [136]. Gong et al. $[137,138]$ reported that a dual injection engine equipped with hydrogen PFI plus methanol DI could effectively extend the lean-burn limit from $\lambda=1.6$ without hydrogen to $\lambda=2.2$ with $3 \%-6 \%$ of hydrogen DI, as well as reduced cyclic variation.

Liquid renewable fuels could also improve the lean-burn performance of dual injection engines. Zhuang et al. [139] reported that the lean-burn limit of a gasoline PFI plus ethanol DI engine was increased by on average 20\% when compared with gasoline PFI. In addition, the lean burn limit increased with the increase of the ethanol ratio and the advance of DI timing. Experiments on a dimethyl ether (DME) PFI plus gasoline DI engine under lean-burn conditions also observed increased thermal efficiency and reduced cyclic variation under dual injection mode [140]. 


\subsection{Higher thermal efficiency and selected emissions reduction}

The ultimate goal of the dual injection concept is to increase engine thermal efficiency and thus to save fossil fuels. This has been well achieved by the advantages discussed above, in particular greater control flexibility, engine downsizing, faster combustion speed and extended lean burn limit. In terms of pollutant emissions, most dual injection studies have reported reductions in particulate and specific gaseous emissions. The detailed effects of dual injection on thermal efficiency and pollutant emissions will be reviewed and discussed in Section 5.

\section{Performance of dual injection engines}

This section discusses the thermal efficiency and pollutant emissions performance of various dual injection engines. It should be noted that the dual injection concept can be applied relatively flexibly so that different fuels are used in dual injection with various combinations, such as dual injection of gasoline plus one renewable fuel (e.g. gasoline PFI + ethanol DI [141]), dual injection of a single fuel (e.g. ethanol PFI + ethanol DI [142]), or dual injection of two renewable fuels (e.g. acetone-butanol-ethanol blend (ABE) PFI + hydrogen DI [143] and hydrogen PFI + methanol DI [144, 145]). However, the supply of renewable fuels is still limited so that they can only partially substitute gasoline use in real world applications. Therefore, this section focuses on dual injection of renewable fuels with gasoline, which is considered as a more effective and efficient method to use renewable fuels in SI engines than pre-blending them with gasoline at fixed ratios. So far, the renewable fuels that have attracted the most research interests in such application are ethanol, methanol and hydrogen. For conciseness, gasoline/ethanol/methanol/hydrogen PFI and gasoline/ethanol/methanol/hydrogen DI are abbreviated as GPI/EPI/MPI/HPI and GDI/EDI/MDI/HDI in this section, respectively.

\subsection{Ethanol-gasoline dual injection engines}

Ethanol is the most popular alternative fuel to gasoline in SI engines and thus has attracted the most research attention for dual injection applications. Compared with gasoline, ethanol has several advantages including a larger RON, a greater enthalpy of vaporisation and a faster laminar flame speed. These advantages make ethanol an ideal anti-knock agent in dual injection engines to implement engine downsizing technologies. Cohn et al. [146] firstly proposed an ethanol boosted engine concept which had the potential to increase the gasoline engine efficiency by approximately 30\%. They proposed to directly inject a small volume of ethanol into the combustion chamber as an anti-knock agent only when high torque output was required, whilst gasoline was delivered via PFI. This could effectively mitigate the engine knock due to ethanol's high RON, and supplemented by the stronger cooling effect due to DI and ethanol's greater enthalpy of vaporisation. The reduced knock propensity made it possible to adopt a high compression ratio and turbocharging in a downsized engine, and consequently to increase the fuel efficiency significantly. A series of patents have been granted based on this concept [93, 95-97]. Similarly, Ford Motor Company introduced 
an EcoBoost turbocharged DI engine in the 2010 Lincoln MKS [147], which used gasoline PFI for starting and light to medium load operation, and E85 DI was only applied to supress knock during high load operation. The EcoBoost engine demonstrated great leveraging effects of E85 in lowering gasoline consumption.

Following that, significant research has been conducted to investigate the performance of ethanolgasoline dual injection engines. Fig. 3 compares the thermal/fuel efficiency performance of various ethanolgasoline dual injection engines. The corresponding engine operation conditions and emissions performance are given in Table 4. Since the most important advantage of ethanol fuel is knock mitigation, most existing studies explored engine performance under knock limited spark timing (KLST) or minimum spark advance for best torque (MBT) conditions while the air fuel ratio (AFR) was kept stoichiometric, as shown in Table 4. Although the original ethanol boosted engine concept proposed to use ethanol via DI, both DI and PFI were explored for ethanol utilisation in the research community, namely GPI+EDI and EPI+GDI. Fig. 3 shows that both dual injection configurations could improve the engine thermal/fuel efficiency compared with single injection, mainly due to ethanol's faster combustion speed and more spark advance allowed by ethanol's anti-knock ability. Regarding the emissions performance, Table 4 shows that both configurations could effectively reduce the PM and PN emissions when compared with GDI [104, 121, 148-151]. For gaseous emissions, the variation trends are highly dependent on engine operating conditions and there are usually trade-offs between emission species such as $\mathrm{NO}_{\mathrm{x}}$ vs $\mathrm{CO} / \mathrm{HC}$ due to their different or conflicting emission formation pathways [152].

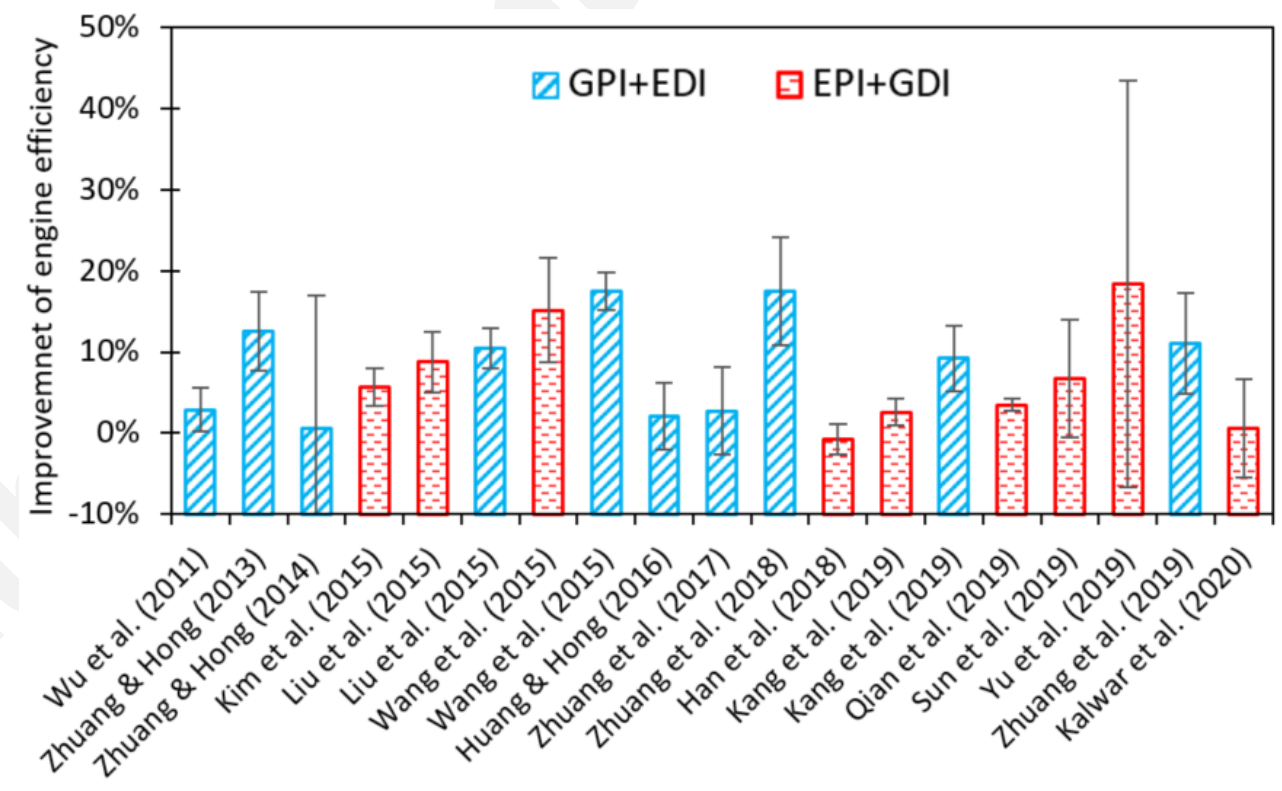

Fig. 3. Improvements in thermal/fuel efficiency of ethanol-gasoline dual injection engines. The results are shown as the mean and range of efficiency improvements observed. 
Table 4. Comparison of emissions performance of ethanol-gasoline dual injection engines.

\begin{tabular}{|c|c|c|c|c|c|c|c|}
\hline \multirow{2}{*}{ Experiments } & \multirow{2}{*}{$\begin{array}{l}\text { Engine conditions (compression ratio, } \\
\text { induction, speed, AFR, spark timing, load) }\end{array}$} & \multirow{2}{*}{$\begin{array}{l}\text { Comparison } \\
\text { baselines* }\end{array}$} & \multicolumn{5}{|c|}{ Emissions performance* } \\
\hline & & & $\mathrm{CO}$ & $\mathrm{HC}$ & $\mathrm{NO}_{\mathrm{x}}$ & PM & PN \\
\hline $\begin{array}{l}\text { Wu et al. (2011) } \\
{[112]}\end{array}$ & $\begin{array}{l}\text { 11.5:1, aspirated, } 1500 \mathrm{rpm}, \lambda=1, \mathrm{KLST}, \\
\mathrm{IMEP}=4.5-8.5 \mathrm{bar}\end{array}$ & GPI+EDI $v s$ GPI & & $\downarrow$ & $\downarrow$ & & \\
\hline $\begin{array}{l}\text { Daniel et al. } \\
(2013)[104]\end{array}$ & $\begin{array}{l}\text { 11.5:1, aspirated, } 1500 \mathrm{rpm}, \lambda=1, \mathrm{KLST} \text {, } \\
\mathrm{IMEP}=5.5 \mathrm{bar}\end{array}$ & $\mathrm{GPI}+\mathrm{E}_{\mathrm{x}} \mathrm{DI} v s \mathrm{E}_{\mathrm{x}} \mathrm{DI}$ & & & & & $\uparrow$ \\
\hline $\begin{array}{l}\text { Zhuang \& Hong } \\
(2013)[113]\end{array}$ & $\begin{array}{l}\text { 9.8:1, aspirated, } 3500-5000 \mathrm{rpm}, \lambda=1,15^{\circ} \\
\text { BTDC, light-medium }\end{array}$ & GPI+EDI $v s$ GPI & $\uparrow$ & $\uparrow$ & $\downarrow$ & & \\
\hline $\begin{array}{l}\text { Zhuang \& Hong } \\
(2014)[153]\end{array}$ & $\begin{array}{l}\text { 9.8:1, aspirated, } 3500-4000 \mathrm{rpm}, \lambda=1 \& \text { lean } \\
\text { burn limit, } 21-25^{\circ} \text { BTDC \& KLST, light- } \\
\text { medium }\end{array}$ & GPI+EDI $v s$ GPI & & $1 \downarrow$ & $1 \downarrow$ & & \\
\hline $\begin{array}{l}\text { Kim et al. } \\
(2015)[121]\end{array}$ & $\begin{array}{l}\text { 9.5/13.3:1, aspirated, } 1000 \mathrm{rpm}, \lambda=1, \mathrm{KLST} \text {, } \\
\text { wide open throttle (WOT) }\end{array}$ & EPI+GDI $v s$ GDI & $\downarrow$ & $1 \downarrow$ & 11 & $\downarrow$ & $\downarrow$ \\
\hline \multirow{2}{*}{$\begin{array}{l}\text { Liu et al. (2015) } \\
{[148]}\end{array}$} & \multirow{2}{*}{$13: 1$, aspirated, $1600 \mathrm{rpm}, \lambda=1, \mathrm{MBT}$, WOT } & EPI+GDI $v s$ GDI & & & & & $\downarrow$ \\
\hline & & GPI+EDI $v s$ GDI & & & & & $\downarrow$ \\
\hline \multirow{2}{*}{$\begin{array}{l}\text { Wang et al. } \\
(2015)[154]\end{array}$} & \multirow{2}{*}{$13: 1$, aspirated, $1600 \mathrm{rpm}, \lambda=1, \mathrm{MBT}$, WOT } & EPI+GDI $v s$ GDI & & & & & \\
\hline & & GPI+EDI $v s$ GDI & & & & & \\
\hline $\begin{array}{l}\text { Huang \& Hong } \\
(2016) \text { [155] }\end{array}$ & $\begin{array}{l}\text { 9.8:1, aspirated, } 3500-4000 \mathrm{rpm}, \lambda=1,15^{\circ} \\
\text { BTDC \& MBT, medium }\end{array}$ & GPI+EDI $v s$ GPI & 1 & $1 \downarrow$ & $\downarrow$ & & \\
\hline $\begin{array}{l}\text { Zhuang et al. } \\
(2017)[122]\end{array}$ & $\begin{array}{l}\text { 9.8:1, aspirated, } 3500 \mathrm{rpm}, \lambda=1, \mathrm{KLSA}, \\
\mathrm{IMEP}=7.2-8.5 \mathrm{bar}\end{array}$ & GPI+EDI $v s$ GDI & $\downarrow$ & 11 & $\uparrow$ & & \\
\hline $\begin{array}{l}\text { Zhuang et al. } \\
(2018) \text { [139] }\end{array}$ & $\begin{array}{l}\text { 9.8:1, aspirated, } 3500-4000 \mathrm{rpm} \text {, lean burn limit, } \\
25^{\circ} \mathrm{BTDC} \text {, IMEP=5.5-7.5bar }\end{array}$ & GPI+EDI $v s$ GPI & & 11 & $\uparrow$ & & \\
\hline $\begin{array}{l}\text { Han et al. (2018) } \\
\text { [149] }\end{array}$ & $\begin{array}{l}\text { 10.5:1, boosted, } 1500 \mathrm{rpm}, \lambda=1, \mathrm{KLST} \\
\text { IMEP=9-13bar }\end{array}$ & $\mathrm{EPI}+\mathrm{GDI} v s \mathrm{E}_{\mathrm{x}} \mathrm{DI}$ & & $\downarrow$ & 11 & & $\downarrow$ \\
\hline \multirow{2}{*}{$\begin{array}{l}\text { Kang et al. } \\
(2019)[50]\end{array}$} & \multirow{2}{*}{$12: 1$, aspirated, $1500 \mathrm{rpm}, \lambda=1, \mathrm{MBT}$, WOT } & EPI+GDI vs GDI & & & & & \\
\hline & & GPI+EDI vs GPI & & & & & \\
\hline $\begin{array}{l}\text { Qian et al. } \\
(2019)[91]\end{array}$ & $\begin{array}{l}\text { 10:1, boosted, } 2000 \mathrm{rpm}, \lambda=1, \mathrm{KLST} \\
\text { BMEP=6bar }\end{array}$ & EPI+GDI $v s$ GDI & $\uparrow$ & $\downarrow$ & $\downarrow$ & & \\
\hline $\begin{array}{l}\text { Sun et al. (2019) } \\
{[150]}\end{array}$ & $\begin{array}{l}\text { 9.6:1, aspirated, } 1500-2100 \mathrm{rpm}, \lambda=1, \mathrm{MBT} \text {, } \\
\text { partial load }\end{array}$ & EPI+GDI $v s$ GDI & & $\downarrow$ & & & $\downarrow$ \\
\hline $\begin{array}{l}\text { Yu et al. (2019) } \\
{[156]}\end{array}$ & $\begin{array}{l}\text { 9.6:1, aspirated, } 1500 \mathrm{rpm}, \lambda=1.0-1.4, \mathrm{MBT} \text {, } \\
\mathrm{IMEP}=2-4 \mathrm{bar}\end{array}$ & EPI+GDI $v s$ EPI & $1 \downarrow$ & $1 \downarrow$ & 11 & & 1 \\
\hline $\begin{array}{l}\text { Zhuang et al. } \\
(2019) \text { [157] }\end{array}$ & $\begin{array}{l}\text { 9.8:1, aspirated, } 3500 \mathrm{rpm}, \lambda=1.0,15^{\circ} \mathrm{BTDC} \text {, } \\
\text { light-medium }\end{array}$ & GPI+EDI $v s$ GPI & 11 & $1 \downarrow$ & $1 \downarrow$ & & \\
\hline $\begin{array}{l}\text { Kalwar et al. } \\
(2020)[151]\end{array}$ & $\begin{array}{l}\text { 10.5: } 1 \text {, aspirated, } 2000 \mathrm{rpm}, \lambda=1.0,24^{\circ} \mathrm{BTDC} \text {, } \\
\text { IMEP=5-7bar }\end{array}$ & EPI+GDI $v s$ GDI & $\downarrow$ & $\uparrow$ & $\downarrow$ & $\downarrow$ & $\downarrow$ \\
\hline
\end{tabular}

* Symbols: $\uparrow$, increased; $\downarrow$, decreased; $1 \downarrow$, depended on operating conditions; Nil, not reported; $\mathrm{E}_{\mathrm{x}}$, ethanol-gasoline blends.

Studies have been conducted to compare engine performance between different dual injection configurations [50, 148, 154, 158]. They all reported that GPI+EDI offered better thermal efficiency than EPI+GDI because EDI could better utilise the cooling effect of ethanol. As a result, the majority of existing studies adopted the dual injection configuration of GPI+EDI. Particularly, Huang and Zhuang et al. have conducted significant works in this area by both experiments and CFD simulations. Firstly, they systematically evaluated the leveraging effect [113, 157], knock mitigation [122, 153] and lean burn performance $[139,153]$ of a GPI+EDI engine under various conditions. The experimental results showed that engine performance was improved by EDI, including higher thermal efficiency, lower $\mathrm{NO}_{\mathrm{x}}$, extended lean 
burn limits and more spark advance without knock issues. However, $\mathrm{CO}$ and $\mathrm{HC}$ were increased by EDI. To understand the underlying mechanisms, CFD simulations [102, 130, 159] and spray experiments [160, 161] were performed to investigate the spray evaporation and combustion processes of the GPI+EDI engine. The CFD results revealed that the flame propagated faster and combustion temperature was lower in GPI+EDI than GPI, leading to higher thermal efficiency and lower $\mathrm{NO}_{\mathrm{x}}$. However, ethanol evaporated slowly under the low-temperature condition before combustion started, causing incomplete combustion. Moreover, overcooling effect and in-cylinder wall wetting occurred when ethanol DI ratio was over 58\%, which worsened the incomplete combustion issue. This led to the increases of $\mathrm{CO}$ and $\mathrm{HC}$ observed in the engine experiments. To address these issues, EDI heating was proposed as an economic and effective method to generate fine and fast evaporating DI sprays in the GPI+EDI engine [155]. The experimental results showed that ethanol fuel heating was an effective method to solve the problems of ethanol's slow evaporation and over-cooling effect in the EDI+GPI engine in terms of minimising the emissions.

\subsection{Methanol-gasoline dual injection engines}

Methanol has a comparable RON and an even higher enthalpy of vaporisation than ethanol. Therefore, methanol is another effective anti-knock agent in dual injection engines to implement engine downsizing technologies. Liu and co-workers have conducted significant experimental works to explore the performance of methanol-gasoline dual injection engines. They found that MPI+GDI could effectively suppress engine knock, extend high-load limits and reduce PN emissions when compared with GDI [120, 162]. They further compared the performance between methanol and ethanol, and found that MPI+GDI had better fuel efficiency and knock mitigation ability than EPI+GDI [127]. Kalwar et al. [151] also observed a higher brake thermal efficiency for MPI+GDI than that of EPI+GDI. This could be attributed to methanol's slightly stronger cooling effect and higher laminar flame velocity than ethanol. Experiments were also conducted to compare the performance of different methanol-gasoline dual injection configurations. Same as for ethanol-gasoline dual injection, they found that GPI+MDI demonstrated higher fuel efficiency, greater anti-knock ability and larger PN reductions than MPI+GDI [148, 154]. The enthalpy of vaporisation of water is even much larger than that of methanol and thus has significant anti-knock potentials. Experiments on a GDI engine showed that KLST could be advanced by water-methanol blends PFI, with pure water PFI having the most advanced KLST [163].

\subsection{Hydrogen-gasoline dual injection engines}

Hydrogen is carbon free and is an attractive alternative fuel for SI engines. Compared with gasoline, the most important advantages of hydrogen are its significantly higher flame velocity, wider flammability limits and lower ignition energy. These advantages make hydrogen an excellent agent to extend the lean burn limit of SI engines, and thus to improve the fuel efficiency. Hydrogen can be introduced into the engine via either PFI or DI, and many studies were conducted to investigate their performance under lean burn conditions. 
Unlike alcohol-gasoline dual injection engines which could vary the alcohol ratio in a wide range from $0 \%$ to $100 \%$, hydrogen-gasoline dual injection engines usually used only a small hydrogen ratio (typically < $15 \%$ ) to partially substitute gasoline fuel.

Ji et al. [164] studied the performance of an HPI+GDI engine under a lean condition of $\lambda=1.2$. Comparing with GDI, HPI+GDI effectively increased the thermal efficiency and significantly reduced the $\mathrm{PN}, \mathrm{CO}$ and $\mathrm{HC}$ emissions and cyclic variation, while $\mathrm{NO}_{\mathrm{x}}$ emissions were increased by hydrogen addition. However, an inherent disadvantage of HPI is the reduced volumetric efficiency because hydrogen displaces air in the intake port [133]. This can be avoided well by HDI after intake valve closes. HDI also has the potential to avoid pre-ignition - another major challenge of HPI - by controlling the DI timing [133]. Therefore, GPI+HDI attracted more research attention. Yu and co-workers carried a series of works on the lean burn performance of GPI+HDI engines. Compared with GPI, GPI+HDI effectively improved the thermal efficiency, expanded the lean burn limit and reduced the cyclic variation [134, 135, 165]. In addition, GPI+HDI had better ignition reliability during cold start [166] and extended the EGR limit [136] than GPI. In terms of emissions performance, $\mathrm{CO}, \mathrm{HC}$ and $\mathrm{PN}$ were greatly reduced while $\mathrm{NO}_{\mathrm{x}}$ was increased by hydrogen addition $[128,167,168]$. The increased $\mathrm{NO}_{\mathrm{x}}$ of GPI+HDI could be controlled by increasing the excess air ratio (e.g. $\lambda=1.5$ ) [128], by using EGR [136] and by split hydrogen injection $[169,170]$. Yu et al. [171] further compared GPI+HDI with GPI+GDI, and reported that GPI+HDI demonstrated larger improvements in thermal and exergy efficiencies with the increase of DI ratio.

\subsection{Other renewable fuel-gasoline dual injection engines}

Although receiving less research attention, other renewable fuels have also been explored for dual injection engines, such as n-butanol, $\mathrm{ABE}, \mathrm{DMF}$ and DME. Compared with gasoline, n-butanol has a comparable RON and moderately higher enthalpy of vaporisation. Therefore, n-butanol is a less effective anti-knock agent when compared with methanol and ethanol. Experiments on a GPI plus n-butanol DI engine showed that dual injection could achieve up to 7\% lower energy consumption than GPI [123]. He et al. [172] and Wang et al. [173] examined the performance of different n-butanol-gasoline dual injection configurations. It was reported that GPI plus n-butanol DI had similar IMEP under a lean condition ( $\lambda=1.3)$ [172] but higher IMEP under stoichiometric and rich $(\lambda=0.9)$ conditions [173] than $n$-butanol PFI plus GDI. Meanwhile, GPI plus n-butanol DI emitted higher PN but lower PM emissions than n-butanol PFI plus GDI [173]. ABE is a solution of acetone, butanol and ethanol, which reduces the separation and purification costs of bio-butanol production. Guo et al. [174-176] investigated the performance of ABE-gasoline dual injection engines. Their results showed that both ABE PFI plus GDI and GPI plus ABE DI could effectively improve the engine combustion and emissions performance compared with the gasoline only condition [174, 175], and GPI plus ABE DI performed better than ABE PFI plus GDI [176].

DMF has a higher RON but lower enthalpy of vaporisation than gasoline. Therefore, the anti-knock ability of DMF is much smaller than that of ethanol and methanol. Experiments on a GPI plus DMF DI engine demonstrated that thermal efficiency was increased at high load, was comparable at medium load but was 
lower at low load when compared with GPI [112]. Meanwhile, $\mathrm{HC}$ was decreased while $\mathrm{NO}_{\mathrm{x}}$ was increased at all loads.

Finally, although DME is considered an alternative fuel to diesel, Shi et al. [140] studied the performance of a DME PFI plus GDI engine under split DI and lean-burn conditions. Compared with GDI, dual injection increased thermal efficiency, reduced $\mathrm{HC}$ and $\mathrm{NO}_{\mathrm{x}}$ emissions, but increased $\mathrm{CO}$ emissions.

\section{Summary and outlook}

This study critically reviewed the dual injection concept for SI engines. It can be concluded that dual injection is an effective and efficient method to use renewable fuels in SI engines. Dual injection offers greater flexibility in the control of mixture formation and combustion processes by integrating the advantages of both DI and PFI technologies and is a promising technology to help achieve the increasingly stringent emission standards. Compared with the conventional single injection engines, the main advantages of dual injection engines include greater control flexibility, enhanced cooling effect, knock mitigation, engine downsizing, faster combustion speed, extended lean-burn limits, higher thermal efficiency, and reductions of some emission species. So far, the renewable fuels that have attracted the most research attention for dual injection SI engines are ethanol, methanol and hydrogen. Each of them is aimed at different advantages of the dual injection concept. Alcohol-gasoline dual injection engines provide great anti-knock ability by taking advantage of alcohols' large enthalpies of vaporisation and high octane numbers, while hydrogen-gasoline dual injection engines provide extended lean-burn limits by taking advantage of hydrogen's low ignition energy, wide flammability limits and fast flame velocity. The renewable fuels can be delivered into the dual injection engines via either PFI or DI. However, renewables DI plus gasoline PFI is the optimal strategy for both alcohol and hydrogen fuels. This is because alcohols DI can better utilise the cooling effect of alcohol fuels which has the same level of importance in knock mitigation as high octane rating of alcohols. Meanwhile, hydrogen DI can effectively avoid volumetric efficiency reductions and pre-ignition by adjusting the DI timing. Regarding the combustion and emissions performance, dual injection engines generally reported higher thermal efficiencies when compared with PFI or DI single injection engines. In addition, dual injection engines could effectively reduce particulate emissions but there were usually trade-offs among gaseous emissions.

Whilst most of the reviewed studies have revealed the benefits of dual injection over conventional single injection, it should be noted that all these studies were conducted under steady state conditions. Future studies are needed to investigate the performance of dual injection engines under transient conditions and to address the challenges of the optimal control of two injection systems. It is expected that increasing production of dual injection cars (but fuelled by one fuel) will be available in the automotive markets, with more mature engine design and global drive for renewable transport fuel. We advocate that future studies investigate practical applications of dual injection of two fuels on real vehicles with a focus on the most promising renewable fuels such as ethanol, methanol and hydrogen that are identified in this study. 


\section{References}

[1] Shuai S, Ma X, Li Y, et al. Recent progress in automotive gasoline direct injection engine technology. Automot Innov 2018;1:95-113.

[2] Kalghatgi G. Is it really the end of internal combustion engines and petroleum in transport? Appl Energy 2018;225:965-974.

[3] Reitz RD, Ogawa H, Payri R, et al. IJER editorial: The future of the internal combustion engine. Int J Engine Res 2020;21:3-10.

[4] World Economic Forum, The number of cars worldwide is set to double by 2040, https://www.weforum.org/agenda/2016/04/the-number-of-cars-worldwide-is-set-to-double-by-2040 <accessed 22.04.2020>.

[5] Kalghatgi G. Development of fuel/engine systems - the way forward to sustainable transport. Engineering 2019;5:510-518.

[6] Yang Z, Bandivadekar A, Light-duty vehicle greenhouse gas and fuel economy standards, International Council on Clean Transportation, 2017.

[7] Huang Y, Ng ECY, Zhou JL, et al. Eco-driving technology for sustainable road transport: A review. Renew Sustain Energy Rev 2018;93:596-609.

[8] International Energy Agency, World energy balances: Overview, 2017.

[9] Anenberg SC, Miller J, Minjares R, et al. Impacts and mitigation of excess diesel-related NOx emissions in 11 major vehicle markets. Nature 2017;545:467-471.

[10] Huang Y, Surawski NC, Yam YS, et al. Re-evaluating effectiveness of vehicle emission control programs targeting high-emitters. Nat Sustain 2020;3:904-907.

[11] Anenberg S, Miller J, Henze D, et al., A global snapshot of the air pollution-related health impacts of transportation sector emissions in 2010 and 2015, The International Council on Clean Transportation, 2019.

[12] European Commission. Commission regulation (EC) No 692/2008 of 18 July 2008. Official Journal of the European Union 2008;199:1-136.

[13] European Commission. Commission regulation (EU) No 459/2012 of 29 May 2012. Official Journal of the European Union 2012;142:16-24.

[14] European Commission. Directive 98/69/EC of the European Parliament and of the Council of 13 October 1998. Official Journal of the European Communities 1998;350:1-56.

[15] European Commission. Commission regulation (EU) 2017/1151 of 1 June 2017. Official Journal of the European Union 2017; 175:1-643.

[16] Tsokolis D, Tsiakmakis S, Dimaratos A, et al. Fuel consumption and CO2 emissions of passenger cars over the New Worldwide Harmonized Test Protocol. Appl Energy 2016;179:1152-1165.

[17] Huang Y, Surawski NC, Organ B, et al. Fuel consumption and emissions performance under real driving: Comparison between hybrid and conventional vehicles. Sci Total Environ 2019;659:275-282.

[18] Fontaras G, Zacharof N-G, Ciuffo B. Fuel consumption and CO2 emissions from passenger cars in Europe - Laboratory versus real-world emissions. Prog Energy Combust Sci 2017;60:97-131.

[19] European Commission, EU action to curb air pollution by cars: Questions and answers (MEMO/17/2821), 2017.

[20] European Commission, Reducing CO2 emissions from passenger cars, 2021, https://ec.europa.eu/clima/policies/transport/vehicles/cars_en <accessed 27.01.2021>.

[21] Huang Z. R \& D current situation and frontier for energy-saving and clean utilization in internal combustion engines. J Automot Safety Energy 2010;1:89-97. 
[22] Zhao F, Lai MC, Harrington DL. Automotive spark-ignited direct-injection gasoline engines. Prog Energy Combust Sci 1999;25:437-562.

[23] Thangavelu SK, Ahmed AS, Ani FN. Review on bioethanol as alternative fuel for spark ignition engines. Renew Sustain Energy Rev 2016;56:820-835.

[24] Awad OI, Mamat R, Ali OM, et al. Alcohol and ether as alternative fuels in spark ignition engine: A review. Renew Sustain Energy Rev 2018;82:2586-2605.

[25] Thakur AK, Kaviti AK, Mehra R, et al. Progress in performance analysis of ethanol-gasoline blends on SI engine. Renew Sustain Energy Rev 2017;69:324-340.

[26] Liu H, Ma G, Ma N, et al. Effects of charge concentration and reactivity stratification on combustion and emission characteristics of a PFI-DI dual injection engine under low load condition. Fuel 2018;231:26-36.

[27] Willems R, Willems F, Deen N, et al. Heat release rate shaping for optimal gross indicated efficiency in a heavy-duty RCCI engine fueled with E85 and diesel. Fuel 2021;288:119656.

[28] Reitz RD, Duraisamy G. Review of high efficiency and clean reactivity controlled compression ignition (RCCI) combustion in internal combustion engines. Prog Energy Combust Sci 2015;46:1271.

[29] Li J, Yang W, Zhou D. Review on the management of RCCI engines. Renew Sustain Energy Rev 2017;69:65-79.

[30] Tang Q, Liu H, Ran X, et al. Effects of direct-injection fuel types and proportion on late-injection reactivity controlled compression ignition. Combust Flame 2020;211:445-455.

[31] Han W, Lu Y, Jin C, et al. Study on influencing factors of particle emissions from a RCCI engine with variation of premixing ratio and total cycle energy. Energy 2020;202:117707.

[32] Qian Y, Zhou Q, Wang X, et al. Enabling dual fuel sequential combustion using port fuel injection of high reactivity fuel combined with direct injection of low reactivity fuels. Appl Therm Eng 2016;103:399-410.

[33] Cui Y, Zheng Z, Wen M, et al. Optical diagnostics on the effects of reverse reactivity stratification on the flame development in dual-fuel combustion. Fuel 2021;287:119500.

[34] Wei L, Geng P. A review on natural gas/diesel dual fuel combustion, emissions and performance. Fuel Process Technol 2016;142:264-278.

[35] Chintala V, Subramanian KA. A comprehensive review on utilization of hydrogen in a compression ignition engine under dual fuel mode. Renew Sustain Energy Rev 2017;70:472-491.

[36] Ghadikolaei MA. Effect of alcohol blend and fumigation on regulated and unregulated emissions of IC engines-A review. Renew Sustain Energy Rev 2016;57:1440-1495.

[37] Zhao W, Li Z, Huang G, et al. Experimental investigation of direct injection dual fuel of n-butanol and biodiesel on Intelligent Charge Compression Ignition (ICCI) Combustion mode. Appl Energy 2020;266:114884.

[38] Li Z, Huang G, Zhang Y, et al. Dual fuel intelligent charge compression ignition (ICCI) combustion: Efficient and clean combustion technology for compression ignition engines. Fuel 2020;279:118565.

[39] Li Y, Jia M, Xu L, et al. Multiple-objective optimization of methanol/diesel dual-fuel engine at low loads: A comparison of reactivity controlled compression ignition (RCCI) and direct dual fuel stratification (DDFS) strategies. Fuel 2020;262:116673.

[40] Shirvani S, Shirvani S, Shamekhi AH, et al. A study of using E10 and E85 under direct dual fuel stratification (DDFS) strategy: Exploring the effects of the reactivity-stratification and diffusionlimited injection on emissions and performance in an E10/diesel DDFS engine. Fuel 2020;275:117870.

[41] Liu X, Srna A, Yip HL, et al. Performance and emissions of hydrogen-diesel dual direct injection (H2DDI) in a single-cylinder compression-ignition engine. Int J Hydrogen Energy 2021;46:13021314. 
[42] Ning L, Duan Q, Kou H, et al. Parametric study on effects of methanol injection timing and methanol substitution percentage on combustion and emissions of methanol/diesel dual-fuel direct injection engine at full load. Fuel 2020;279:118424.

[43] Venugopal T, Ramesh A. Effective utilisation of butanol along with gasoline in a spark ignition engine through a dual injection system. Appl Therm Eng 2013;59:550-558.

[44] Venugopal T, Ramesh A. Experimental studies on the effect of injection timing in a SI engine using dual injection of n-butanol and gasoline in the intake port. Fuel 2014;115:295-305.

[45] Thangavel V, Momula SY, Gosala DB, et al. Experimental studies on simultaneous injection of ethanol-gasoline and n-butanol-gasoline in the intake port of a four stroke SI engine. Renew Energ 2016;91:347-360.

[46] Ji C, Shi L, Wang S, et al. Investigation on performance of a spark-ignition engine fueled with dimethyl ether and gasoline mixtures under idle and stoichiometric conditions. Energy 2017;126:335-342.

[47] Lee SY, Lee HJ, Kang YT, et al. Effects of injection strategies on the flow and fuel behavior characteristics in port dual injection engine. Energy 2018;165:666-676.

[48] Lee Y, Oh S, Kim C, et al. The dual-port fuel injection system for fuel economy improvement in an automotive spark-ignition gasoline engine. Appl Therm Eng 2018;138:300-306.

[49] Wong KI, Wong PK. Adaptive air-fuel ratio control of dual-injection engines under biofuel blends using extreme learning machine. Energy Convers Manage 2018;165:66-75.

[50] Kang R, Zhou L, Hua J, et al. Experimental investigation on combustion characteristics in dual-fuel dual-injection engine. Energy Convers Manage 2019;181:15-25.

[51] Li J, Liu C, Kang R, et al. Effects of the injection timing on knock and combustion characteristics in dual-fuel dual-injection engines. Proc Inst Mech Eng D 2020;234:2578-2591.

[52] Román-Leshkov Y, Barrett CJ, Liu ZY, et al. Production of dimethylfuran for liquid fuels from biomass-derived carbohydrates. Nature 2007;447:982-985.

[53] Zhao H, Holladay JE, Brown H, et al. Metal chlorides in ionic liquid solvents convert sugars to 5Hydroxymethylfurfural. Science 2007;316:1597-1600.

[54] Bechtold RL. Alternative fuels guidebook: Properties, storage, dispensing and vehicle facility modifications. SAE International, 1997.

[55] Heywood JB. Internal combustion engine fundamentals (2nd edition). McGraw Hill Education, 2018.

[56] Crowl DA, Jo Y-D. The hazards and risks of hydrogen. J Loss Prev Process Ind 2007;20:158-164.

[57] Liu H, Xu J, Zheng Z, et al. Effects of fuel properties on combustion and emissions under both conventional and low temperature combustion mode fueling 2,5-dimethylfuran/diesel blends. Energy 2013;62:215-223.

[58] Glassman I. Combustion (3rd edition). Academic Press, 1996.

[59] Balat M. Production of bioethanol from lignocellulosic materials via the biochemical pathway: A review. Energy Convers Manage 2011;52:858-875.

[60] Safety Management Services Inc., Data guides, 1999, http://www.smsenergetics.com/wpcontent/uploads/2015/11/Data Guides.pdf.

[61] Wei H, Feng D, Shu G, et al. Experimental investigation on the combustion and emissions characteristics of 2-methylfuran gasoline blend fuel in spark-ignition engine. Appl Energy 2014;132:317-324.

[62] Wallner T, Miers SA, McConnell S. A comparison of ethanol and butanol as oxygenates using a directinjection, spark-ignition engine. J Eng Gas Turbine Power 2009;131:032802.

[63] Topgül T. The effects of MTBE blends on engine performance and exhaust emissions in a spark ignition engine. Fuel Process Technol 2015;138:483-489.

[64] National Library of Medicine, Tert-butyl ethyl ether, 2020, https://pubchem.ncbi.nlm.nih.gov/compound/Tert-Butyl-ethyl-ether <accessed 12.07.2020>. 
[65] Addepally U, Thulluri C. Recent progress in production of fuel range liquid hydrocarbons from biomass-derived furanics via strategic catalytic routes. Fuel 2015;159:935-942.

[66] Bae C, Kim J. Alternative fuels for internal combustion engines. Proc Combust Inst 2017;36:33893413.

[67] Li Q, Zhang W, Jin W, et al. Laminar flame characteristics and kinetic modeling study of methanolisooctane blends at elevated temperatures. Fuel 2016;184:836-845.

[68] Wu F, Law CK. An experimental and mechanistic study on the laminar flame speed, Markstein length and flame chemistry of the butanol isomers. Combust Flame 2013;160:2744-2756.

[69] Hu E, Ku J, Yin G, et al. Laminar flame characteristics and kinetic modeling study of ethyl tertiary butyl ether compared with methyl tertiary butyl ether, ethanol, iso-octane, and gasoline. Energy Fuels 2018;32:3935-3949.

[70] Yahyaoui M, Djebaili-Chaumeix N, Dagaut P, et al. Ethyl tertiary butyl ether ignition and combustion using a shock tube and spherical bomb. Energy Fuels 2008;22:3701-3708.

[71] Ma X, Jiang C, Xu H, et al. Laminar burning characteristics of 2-methylfuran and isooctane blend fuels. Fuel 2014;116:281-291.

[72] Tian G, Daniel R, Li H, et al. Laminar burning velocities of 2,5-dimethylfuran compared with ethanol and gasoline. Energy Fuels 2010;24:3898-3905.

[73] Elearning@Cerfacs, Adiabatic flame temperature calculator, 2020, http://elearning.cerfacs.fr/combustion/tools/adiabaticflametemperature/index.php $\quad<$ accessed 12.07.2020>.

[74] Larsson T, Stenlaas O, Erlandsson A, Future fuels for DISI engines: A review on oxygenated, liquid biofuels. SAE Paper 2019-01-0036, 2019.

[75] Pulkrabek WW. Engineering fundamentals of the internal combustion engine. Prentice Hall, 1997.

[76] Lee Z, Kim T, Park S, et al. Review on spray, combustion, and emission characteristics of recent developed direct-injection spark ignition (DISI) engine system with multi-hole type injector. Fuel 2020;259:116209.

[77] Rotondi R, Bella G. Gasoline direct injection spray simulation. Int J Therm Sci 2006;45:168-179.

[78] Saliba G, Saleh R, Zhao Y, et al. Comparison of gasoline direct-injection (GDI) and port fuel injection (PFI) vehicle emissions: Emission certification standards, cold-start, secondary organic aerosol formation potential, and potential climate impacts. Environ Sci Technol 2017;51:6542-6552.

[79] Liang B, Ge Y, Tan J, et al. Comparison of PM emissions from a gasoline direct injected (GDI) vehicle and a port fuel injected (PFI) vehicle measured by electrical low pressure impactor (ELPI) with two fuels: Gasoline and M15 methanol gasoline. J Aerosol Sci 2013;57:22-31.

[80] Su J, Lin W, Sterniak J, et al. Particulate matter emission comparison of spark ignition direct injection (SIDI) and port fuel injection (PFI) operation of a boosted gasoline engine. J Eng Gas Turbine Power $2014 ; 136$.

[81] Zhu R, Hu J, Bao X, et al. Tailpipe emissions from gasoline direct injection (GDI) and port fuel injection (PFI) vehicles at both low and high ambient temperatures. Environ Pollut 2016;216:223-234.

[82] $\mathrm{He} \mathrm{L}, \mathrm{Hu} \mathrm{J}$, Zhang S, et al. The impact from the direct injection and multi-port fuel injection technologies for gasoline vehicles on solid particle number and black carbon emissions. Appl Energy 2018;226:819-826.

[83] Wen M, Zhang C, Yue Z, et al. Effects of Gasoline Octane Number on Fuel Consumption and Emissions in Two Vehicles Equipped with GDI and PFI Spark-Ignition Engine. J Energy Eng 2020;146:04020069.

[84] Qian Y, Li Z, Yu L, et al. Review of the state-of-the-art of particulate matter emissions from modern gasoline fueled engines. Appl Energy 2019;238:1269-1298. 
[85] Awad OI, Ma X, Kamil M, et al. Particulate emissions from gasoline direct injection engines: A review of how current emission regulations are being met by automobile manufacturers. Sci Total Environ 2020;718:137302.

[86] Xu H, Wang C, Ma X, et al. Fuel injector deposits in direct-injection spark-ignition engines. Prog Energy Combust Sci 2015;50:63-80.

[87] Cohn DR, Bromberg L, Port injection system for reduction of particulates from turbocharged direct injection gasoline engines, 2018, US Patent US20180238245A1.

[88] Chen W, Xia C, Zhu L, et al. An experimental study on combustion and particulate emissions characteristics on a dual-injection gasoline engine. Appl Therm Eng 2019;156:722-729.

[89] Grubel K, Chouyyok W, Heldebrant DJ, et al. Octane-on-demand: Onboard separation of oxygenates from gasoline. Energy Fuels 2019;33:1869-1881.

[90] Chishima H, Tsutsumi D, Kitamura T, Onboard ethanol-gasoline separation system for octane-ondemand vehicle. SAE Paper 2020-01-0350, 2020.

[91] Qian Y, Liu G, Guo J, et al. Engine performance and octane on demand studies of a dual fuel spark ignition engine with ethanol/gasoline surrogates as fuel. Energy Convers Manage 2019;183:296-306.

[92] Morganti K, Viollet Y, Head R, et al. Maximizing the benefits of high octane fuels in spark-ignition engines. Fuel 2017;207:470-487.

[93] Bromberg L, Blumberg PN, Cohn DR, et al., Fuel tank system for direct ethanol injection octane boosted gasoline engine, 2010, US Patent US7726265B2.

[94] Bromberg L, Cohn DR, Fuel management system for very high efficiency flex fuel engines powered by methanol and gasoline, 2014, US Patent US8677949B2.

[95] Bromberg L, Cohn DR, Minimizing alcohol use in high efficiency alcohol boosted gasoline engines, 2016, US Patent 9273618B2.

[96] Cohn DR, Heywood JB, Bromberg L, Fuel management system for variable ethanol octane enhancement of gasoline engines, 2017, US Patent US9810166B2.

[97] Bromberg L, Cohn DR, Heywood JB, Optimized fuel management system for direct injection ethanol enhancement of gasoline engines, 2019, US Patent US10221783B2.

[98] Phuangwongtrakul S, Wechsatol W, Sethaput T, et al. Experimental study on sparking ignition engine performance for optimal mixing ratio of ethanol-gasoline blended fuels. Appl Therm Eng 2016;100:869-879.

[99] Schifter I, Diaz L, Rodriguez R, et al. Combustion and emissions behavior for ethanol-gasoline blends in a single cylinder engine. Fuel 2011;90:3586-3592.

[100] Turner D, Xu H, Cracknell RF, et al. Combustion performance of bio-ethanol at various blend ratios in a gasoline direct injection engine. Fuel 2011;90:1999-2006.

[101] Sakthivel P, Subramanian KA, Mathai R. Experimental study on unregulated emission characteristics of a two-wheeler with ethanol-gasoline blends (E0 to E50). Fuel 2020;262:116504.

[102] Huang Y, Hong G, Huang R. Investigation to charge cooling effect and combustion characteristics of ethanol direct injection in a gasoline port injection engine. Appl Energy 2015;160:244-254.

[103] Daniel R, Xu H, Wang C, et al. Combustion performance of 2,5-dimethylfuran blends using dualinjection compared to direct-injection in a SI engine. Appl Energy 2012;98:59-68.

[104] Daniel R, Xu H, Wang C, et al. Gaseous and particulate matter emissions of biofuel blends in dualinjection compared to direct-injection and port injection. Appl Energy 2013;105:252-261.

[105] Kar K, Last T, Haywood C, et al. Measurement of vapor pressures and enthalpies of vaporization of gasoline and ethanol blends and their effects on mixture preparation in an SI engine. SAE Int J Fuels Lubr 2009; 1:132-144.

[106] Price P, Twiney B, Stone R, et al., Particulate and hydrocarbon emissions from a spray guided direct injection spark ignition engine with oxygenate fuel blends. SAE paper 2007-01-0472, 2007. 
[107] Anbari Attar M, Herfatmanesh MR, Zhao H, et al. Experimental investigation of direct injection charge cooling in optical GDI engine using tracer-based PLIF technique. Exp Therm Fluid Sci 2014;59:96108.

[108] Ahn K-h, Yilmaz H, Stefanopoulou A, et al., Ethanol content estimation in flex fuel direct injection engines using in-cylinder pressure measurements. SAE paper 2010-01-0166, 2010.

[109] Wyszynski LP, Stone CR, Kalghatgi GT, The volumetric efficiency of direct and port injection gasoline engines with different fuels. SAE paper 2002-01-0839, 2002.

[110] Kasseris E, Heywood JB, Charge cooling effects on knock limits in SI DI engines using gasoline/ethanol blends: Part 1 - quantifying charge cooling. SAE paper 2012-01-1275, 2012.

[111] Kasseris E, Heywood JB. Charge cooling effects on knock limits in SI DI engines using gasoline/ethanol blends: Part 2 - effective octane numbers. SAE Int J Fuels Lubr 2012;5:844-854.

[112] Wu X, Daniel R, Tian G, et al. Dual-injection: The flexible, bi-fuel concept for spark-ignition engines fuelled with various gasoline and biofuel blends. Appl Energy 2011;88:2305-2314.

[113] Zhuang Y, Hong G. Primary investigation to leveraging effect of using ethanol fuel on reducing gasoline fuel consumption. Fuel 2013;105:425-431.

[114] Zhuang Y, Hong G, Investigation to leveraging effect of ethanol direct injection (EDI) in a gasoline port injection (GPI) engine. SAE paper 2013-01-1322, 2013.

[115] Stein RA, Polovina D, Roth K, et al. Effect of heat of vaporization, chemical octane, and sensitivity on knock limit for ethanol-gasoline blends. SAE Int J Fuels Lubr 2012;5:823-843.

[116] Milpied J, Jeuland N, Plassat G, et al. Impact of fuel properties on the performances and knock behaviour of a downsized turbocharged DI SI engine - focus on octane numbers and latent heat of vaporization. SAE Int J Fuels Lubr 2009;2:118-126.

[117] Ozsezen AN, Canakci M. Performance and combustion characteristics of alcohol-gasoline blends at wide-open throttle. Energy 2011;36:2747-2752.

[118] Huang Y, Hong G, Cheng X, et al., Investigation to charge cooling effect of evaporation of ethanol fuel directly injected in a gasoline port injection engine. SAE paper 2013-01-2610, 2013.

[119] Srivastava S, Schock H, Jaberi F, et al., Numerical simulation of a direct-injection spark-ignition engine with different fuels. SAE paper 2009-01-0325, 2009.

[120] Liu H, Wang Z, Wang J. Methanol-gasoline DFSI (dual-fuel spark ignition) combustion with dualinjection for engine knock suppression. Energy 2014;73:686-693.

[121] Kim N, Cho S, Min K. A study on the combustion and emission characteristics of an SI engine under full load conditions with ethanol port injection and gasoline direct injection. Fuel 2015;158:725-732.

[122] Zhuang Y, Qian Y, Hong G. The effect of ethanol direct injection on knock mitigation in a gasoline port injection engine. Fuel 2017;210:187-197.

[123] Feng D, Wei H, Pan M, et al. Combustion performance of dual-injection using n-butanol directinjection and gasoline port fuel-injection in a SI engine. Energy 2018;160:573-581.

[124] Fraser N, Blaxill H, Lumsden G, et al. Challenges for increased efficiency through gasoline engine downsizing. SAE Int J Engines 2009;2:991-1008.

[125] Gheorghiu V, Ultra-downsizing of internal combustion engines. SAE paper 2015-01-1252, 2015.

[126] Turner JWG, Popplewell A, Patel R, et al. Ultra boost for economy: Extending the limits of extreme engine downsizing. SAE Int J Engines 2014;7:387-417.

[127] Liu H, Wang Z, Long Y, et al. Dual-fuel spark ignition (DFSI) combustion fuelled with different alcohols and gasoline for fuel efficiency. Fuel 2015;157:255-260.

[128] Du Y, Yu X, Wang J, et al. Research on combustion and emission characteristics of a lean burn gasoline engine with hydrogen direct-injection. Int J Hydrogen Energy 2016;41:3240-3248.

[129] Jiang C, Ma X, Xu H, et al., An optical study of DMF and ethanol combustion under dual-injection strategy. SAE paper 2012-01-1237, 2012. 
[130] Huang Y, Hong G, Huang R. Numerical investigation to the dual-fuel spray combustion process in an ethanol direct injection plus gasoline port injection (EDI + GPI) engine. Energy Convers Manage 2015;92:275-286.

[131] Alvarez CEC, Couto GE, Roso VR, et al. A review of prechamber ignition systems as lean combustion technology for SI engines. Appl Therm Eng 2018;128:107-120.

[132] Morsy MH. Review and recent developments of laser ignition for internal combustion engines applications. Renew Sustain Energy Rev 2012;16:4849-4875.

[133] White CM, Steeper RR, Lutz AE. The hydrogen-fueled internal combustion engine: a technical review. Int J Hydrogen Energy 2006;31:1292-1305.

[134] Niu R, Yu X, Du Y, et al. Effect of hydrogen proportion on lean burn performance of a dual fuel SI engine using hydrogen direct-injection. Fuel 2016;186:792-799.

[135] Yu X, Du Y, Sun P, et al. Effects of hydrogen direct injection strategy on characteristics of lean-burn hydrogen-gasoline engines. Fuel 2017;208:602-611.

[136] Yu X, Guo Z, He L, et al. Experimental study on lean-burn characteristics of an SI engine with hydrogen/gasoline combined injection and EGR. Int J Hydrogen Energy 2019;44:13988-13998.

[137] Gong C, Li Z, Yi L, et al. Experimental investigation of equivalence ratio effects on combustion and emissions characteristics of an $\mathrm{H} 2$ /methanol dual-injection engine under different spark timings. Fuel 2020;262:116463.

[138] Gong C, Li Z, Yi 1, et al. Research on the performance of a hydrogen/methanol dual-injection assisted spark-ignition engine using late-injection strategy for methanol. Fuel 2020;260:116403.

[139] Zhuang Y, Qian Y, Hong G. Lean burn performance of a spark ignition engine with an ethanolgasoline dual injection system. Energy Fuels 2018;32:2855-2868.

[140] Shi L, Ji C, Wang S, et al. Impacts of dimethyl ether enrichment and various injection strategies on combustion and emissions of direct injection gasoline engines in the lean-burn condition. Fuel 2019;254:115636.

[141] Zhuang Y, Ma Y, Qian Y, et al. Effects of ethanol injection strategies on mixture formation and combustion process in an ethanol direct injection (EDI) plus gasoline port injection (GPI) sparkignition engine. Fuel 2020;268:117346.

[142] Al-Muhsen NFO, Huang Y, Hong G. Effects of direct injection timing associated with spark timing on a small spark ignition engine equipped with ethanol dual-injection. Fuel 2019;239:852-861.

[143] Yu X, Li D, Yang S, et al. Effects of hydrogen direct injection on combustion and emission characteristics of a hydrogen/Acetone-Butanol-Ethanol dual-fuel spark ignition engine under lean-burn conditions. Int J Hydrogen Energy 2020;45:34193-34203.

[144] Gong C, Li Z, Yi L, et al. Comparative analysis of various combustion phase control methods in a lean-burn H2/methanol fuel dual-injection engine. Fuel 2020;262:116592.

[145] Gong C, Li Z, Sun J, et al. Evaluation on combustion and lean-burn limit of a medium compression ratio hydrogen/methanol dual-injection spark-ignition engine under methanol late-injection. Appl Energy 2020;277:115622.

[146] Cohn DR, Bromberg L, Heywood JB, Direct injection ethanol boosted gasoline engines: Biofuel leveraging for cost effective reduction of oil dependence and $\mathrm{CO} 2$ emissions, Massachusetts Institute of Technology, 2005.

[147] Stein RA, House CJ, Leone TG. Optimal use of E85 in a turbocharged direct injection engine. SAE Int J Fuels Lubr 2009;2:670-682.

[148] Liu H, Wang Z, Long Y, et al. Comparative study on alcohol-gasoline and gasoline-alcohol DualFuel Spark Ignition (DFSI) combustion for engine particle number (PN) reduction. Fuel 2015;159:250258.

[149] Han T, Lavoie G, Wooldridge M, et al., Dual fuel injection (DI + PFI) for knock and EGR dilution limit extension in a boosted SI engine. SAE Paper 2018-01-1735, 2018. 
[150] Sun P, Liu Z, Dong W, et al. Comparative study on the effects of ethanol proportion on the particle numbers emissions in a combined injection engine. Energies 2019;12:1788.

[151] Kalwar A, Singh AP, Agarwal AK. Utilization of primary alcohols in dual-fuel injection mode in a gasoline direct injection engine. Fuel 2020;276:118068.

[152] Huang Y, Organ B, Zhou JL, et al. Characterisation of diesel vehicle emissions and determination of remote sensing cutpoints for diesel high-emitters. Environ Pollut 2019;252:31-38.

[153] Zhuang Y, Hong G. Effects of direct injection timing of ethanol fuel on engine knock and lean burn in a port injection gasoline engine. Fuel 2014;135:27-37.

[154] Wang Z, Liu H, Long Y, et al. Comparative study on alcohols-gasoline and gasoline-alcohols dualfuel spark ignition (DFSI) combustion for high load extension and high fuel efficiency. Energy 2015;82:395-405.

[155] Huang Y, Hong G. Investigation of the effect of heated ethanol fuel on combustion and emissions of an ethanol direct injection plus gasoline port injection (EDI + GPI) engine. Energy Convers Manage 2016;123:338-347.

[156] Yu X, Guo Z, Sun P, et al. Investigation of combustion and emissions of an SI engine with ethanol port injection and gasoline direct injection under lean burn conditions. Energy 2019;189:116231.

[157] Zhuang Y, Zhu G, Gong Z, et al. Experimental and numerical investigation of performance of an ethanol-gasoline dual-injection engine. Energy 2019;186:115835.

[158] Zhu G, Hung D, Schock H. Combustion characteristics of a single-cylinder spark ignition gasoline and ethanol dual-fuelled engine. Proc Inst Mech Eng D 2010;224:387-403.

[159] Huang Y, Hong G, Huang R. Effect of injection timing on mixture formation and combustion in an ethanol direct injection plus gasoline port injection (EDI+GPI) engine. Energy 2016;111:92-103.

[160] Huang Y, Huang S, Deng P, et al. The effect of fuel temperature on the ethanol direct injection spray characteristics of a multi-hole injector. SAE Int J Fuels Lubr 2014;7:792-802.

[161] Huang Y, Huang S, Huang R, et al. Spray and evaporation characteristics of ethanol and gasoline direct injection in non-evaporating, transition and flash-boiling conditions. Energy Convers Manage 2016;108:68-77.

[162] Liu H, Wang Z, Long Y, et al. Methanol-gasoline dual-fuel spark ignition (DFSI) combustion with dual-injection for engine particle number $(\mathrm{PN})$ reduction and fuel economy improvement. Energy 2015;89:1010-1017.

[163] Miganakallu N, Yang Z, Rogóż R, et al. Effect of water - methanol blends on engine performance at borderline knock conditions in gasoline direct injection engines. Appl Energy 2020;264:114750.

[164] Ji C, Cong X, Wang S, et al. Performance of a hydrogen-blended gasoline direct injection engine under various second gasoline direct injection timings. Energy Convers Manage 2018;171:1704-1711.

[165] Yu X, Wu H, Du Y, et al. Research on cycle-by-cycle variations of an SI engine with hydrogen direct injection under lean burn conditions. Appl Therm Eng 2016;109:569-581.

[166] Wu H, Yu X, Du Y, et al. Study on cold start characteristics of dual fuel SI engine with hydrogen direct-injection. Appl Therm Eng 2016;100:829-839.

[167] He F, Li S, Yu X, et al. Comparison study and synthetic evaluation of combined injection in a spark ignition engine with hydrogen-blended at lean burn condition. Energy 2018;157:1053-1062.

[168] Sun Y, Yu X, Jiang L. Effects of direct hydrogen injection on particle number emissions from a lean burn gasoline engine. Int J Hydrogen Energy 2016;41:18631-18640.

[169] Li G, Yu X, Jin Z, et al. Study on effects of split injection proportion on hydrogen mixture distribution, combustion and emissions of a gasoline/hydrogen SI engine with split hydrogen direct injection under lean burn condition. Fuel 2020;270:117488.

[170] Li G, Yu X, Shi W, et al. Effects of split injection proportion and the second injection timings on the combustion and emissions of a dual fuel SI engine with split hydrogen direct injection. Int J Hydrogen Energy 2019;44:11194-11204. 
[171] Yu X, Li D, Sun P, et al. Energy and exergy analysis of a combined injection engine using gasoline port injection coupled with gasoline or hydrogen direct injection under lean-burn conditions. Int $\boldsymbol{J}$ Hydrogen Energy 2020.

[172] He B-Q, Chen X, Lin C-L, et al. Combustion characteristics of a gasoline engine with independent intake port injection and direct injection systems for n-butanol and gasoline. Energy Convers Manage 2016;124:556-565.

[173] Wang Y, Yu X, Ding Y, et al. Experimental comparative study on combustion and particle emission of n-butanol and gasoline adopting different injection approaches in a spark engine equipped with dualinjection system. Fuel 2018;211:837-849.

[174] Guo Z, Yu X, Dong W, et al. Research on the combustion and emissions of an SI engine with acetonebutanol-ethanol (ABE) port injection plus gasoline direct injection. Fuel 2020;267:117311.

[175] Guo Z, Yu X, Sang T, et al. Experimental study on combustion and emissions of an SI engine with gasoline port injection and acetone-butanol-ethanol (ABE) direct injection. Fuel 2021;284:119037.

[176] Guo Z, Yu X, Li G, et al. Comparative study of different injection modes on combustion and particle emission of acetone-butanol-ethanol (ABE) and gasoline in a dual-injection SI engine. Fuel 2020;281:118786. 